Cornell University Law School Scholarship@Cornell Law: A Digital Repository

$11-2017$

\title{
Unprecedented? Judicial Confirmation Battles and the Search for a Usable Past
}

Josh Chafetz

Cornell Law School, jc2284@cornell.edu

Follow this and additional works at: http://scholarship.law.cornell.edu/facpub

Part of the Constitutional Law Commons, Judges Commons, and the Law and Politics Commons

\section{Recommended Citation}

Chafetz, Josh, "Unprecedented? Judicial Confirmation Battles and the Search for a Usable Past," 131 Harvard Law Review 96-132 (2017)

This Article is brought to you for free and open access by the Faculty Scholarship at Scholarship@Cornell Law: A Digital Repository. It has been accepted for inclusion in Cornell Law Faculty Publications by an authorized administrator of Scholarship@Cornell Law: A Digital Repository. For more information, please contact jmp8@cornell.edu. 


\title{
ESSAY \\ UNPRECEDENTED? \\ JUDICIAL CONFIRMATION BATTLES AND THE SEARCH FOR A USABLE PAST
}

\author{
Josh Chafetz*
}

"Unprecedented" is a dirty word - at least in the context of constitutional politics. The claim that some behavior is unprecedented carries with it a distinct whiff of impermissibility: if it's never been done before, then at the very least the burden is on those who would want to do it to show that it is permissible. ${ }^{1}$ A thumb is very firmly placed on the scale against constitutional novelty. The claim that some activity is constitutionally novel is therefore a politically potent one.

Of course, to call one act a "precedent" for another is not to state a fact about the relationship between them but rather to engage in a creative act of interpretation. Precedential relationships are made, not found, ${ }^{2}$ and therefore charges of unprecedentedness represent a political judgment - but one that comes in the guise of a discovery of a fact about the world. In recent years, perhaps nowhere has unprecedented behavior been "discovered" with more abandon than in the context of judicial appointments. Part I of this Essay describes recent events in this domain, beginning in the George W. Bush Administration and culminating with the 2017 elimination of the filibuster for all nominees. In particular, it focuses on the discourse surrounding these reforms, noting that at every turn, accusations of "unprecedented" behavior have flown in all directions and have served as justifications for countermeasures, which are in turn characterized as unprecedented. Part II then reconstructs two pasts - two precedential pathways - for recent events, one drawing on the history of legislative obstruction and the other on the

\footnotetext{
* Professor of Law, Cornell Law School. I am grateful to Will Baude, Mike Dorf, Joey Fishkin, Randy Kozel, Marin Levy, David Pozen, Aziz Rana, Catherine Roach, and Justin Zaremby for helpful and thought-provoking comments on earlier drafts. The research and writing of this Essay were funded in part by a gift from the Charles Adelman Fund at Cornell Law School. I gratefully acknowledge the generosity of Charles Adelman and the support his gift provides to legal scholarship. Any remaining errors or infelicities are, of course, my own.

1 This is notably true in that subset of constitutional politics that consists of judicial decisionmaking. For instance, claims that the individual mandate imposed by the Affordable Care Act was unprecedented did quite a bit of work in NFIB v. Sebelius, 567 U.S. 5I9, 547-58 (20I2) (Roberts, C.J.); id. at 649-6o (Scalia, Kennedy, Thomas, and Alito, JJ., dissenting). For a cogent attack on this principle in the context of judicial decisions, see Leah M. Litman, Debunking Antinovelty, 66 DUKE L.J. I407 (2017).

2 This observation is hardly original. See, e.g., JEROME FRAnk, LAw AND THE Modern MIND I48-59 (I930).
} 
history of confirmation politics. The purpose of these historical narratives is not to adjudicate particular claims of unprecedentedness but rather to highlight the ways in which any claim of (un)precedentedness involves particular, contestable constructions of the past. The Essay concludes with some thoughts about why we might prefer some available pasts to others.

\section{THE PRESENT}

By the middle of 2004 , Republicans were furious. Three years into George W. Bush's presidency, they were having at best very limited success in stocking the federal courts, and especially the circuit courts, with their preferred personnel. Democrats had held the Senate majority for most of the I07th Congress (200I-2003), ${ }^{3}$ and they had used their power to good effect, confirming only $52 \%$ of Bush's ${ }^{4}$ nominees to the courts of appeals. ${ }^{5}$ But Republicans retook the Senate in the 2002 midterms and clearly expected the pace of appointments to pick up. Orrin Hatch, who became chair of the Judiciary Committee, announced that he would dial down the deference traditionally given to home-state senators, holding hearings and votes even for nominees opposed by both home-state senators. ${ }^{6}$ Of the seven appeals-court nominees in that Congress who did not have the approvals of both home-state senators, five were voted out of committee. ${ }^{7}$ Patrick Leahy, the ranking Democrat on the Judiciary Committee, solemnly intoned that this move would "be long remembered in the annals of the Senate and of our committee for the precedent set by [holding a hearing on a nominee over the objection of

\footnotetext{
3 Republicans controlled the Senate between January 20 and June 6, 2001, but after Senator James Jeffords began caucusing with the Democrats, the Democrats controlled the chamber for the rest of the ro 7 th Congress. See Josh Chafetz, A Fourth Way? Bringing Politics Back into Recess Appointments (And the Rest of the Separation of Powers, Too), 64 DUKE L.J. ONLINE I6I, I70 n.39 (2015).

4 Given the frequency with which Presidents, members of Congress, and judges are mentioned, this Essay purposefully deviates from the Harvard Law Review's custom of using the titles of all political officeholders whenever they are mentioned.

5 Sheldon Goldman, Judicial Confirmation Wars: Ideology and the Battle for the Federal Courts, 39 U. RICH. L. REV. 87 I, 905 tbl.2 (2005). Throughout, following the Goldman article series, I use "courts of appeals" to refer to the courts of appeals of general jurisdiction — that is, to exclude the Court of Appeals for the Federal Circuit. For the Io7th Congress in particular, this tally also omits the eight nominees submitted by President Clinton at the beginning of the Congress and withdrawn by President Bush two months later. See S. REP. NO. I08-152, at 22-26 (2003) (listing the names of the withdrawn nominees).

6 See Mitchel A. Sollenberger, The Blue Slip: A Theory of Unified and Divided Government, 1979-2009, 37 CONGRESS \& PRESIDENCY I25, I43-46 (2010). On the tradition of senatorial courtesy and blue slips generally, see Josh CHAFETZ, ConGREss's CoNSTITUTION: LEGISLATIVE AUTHority AND THE SEPARATION OF POWERS I26 (20I7).

7 Sollenberger, supra note 6, at 144 tbl.2.
} 
both home-state senators], for the hubris behind it and for the brazenness of the double standard it sets." Majority Leader Bill Frist was unmoved; when the nominees came to the floor, he declined to honor hold requests on them. ${ }^{9}$ Democrats responded by increasing the use of filibusters against those, and other, nominees. ${ }^{10}$ None of the nominees lacking the support of their home-state senators were confirmed in that Congress. ${ }^{11}$ In the end, the Republicans' record in the Io8th Congress was no better than in the ro7th: $53 \%$ of Bush's nominees to the circuit courts were confirmed. ${ }^{12}$ (It should be noted that the confirmation of district judges was significantly less contentious, with $85 \%$ and $90 \%$ of nominees confirmed in the ro7th and ro8th Congresses, respectively. ${ }^{13}$ One Democratic Senate aide during this period suggested that this was evidence of Democrats' "pick[ing] their fights" — that is, holding their fire for the more ideologically freighted appellate nominees. ${ }^{14}$ )

Of the sixteen failed court-of-appeals nominations in the ro8th Congress, ten involved at least one failed cloture vote on the Senate floor — in other words, the nominations failed because a filibuster could not be broken. ${ }^{15}$ Several involved multiple failed cloture votes: for instance, backers attempted to invoke cloture on Miguel Estrada's nomination to the D.C. Circuit on seven occasions between March and July 2003 , but none of those attempts received more than fifty-five votes in favor, and his nomination was withdrawn in September of that year. ${ }^{16}$ The remaining six nominees were never brought to the floor at all. ${ }^{17}$

In this context, President Bush decided to heighten the conflict. Declaring that "a minority of Democratic Senators has been using unprecedented obstructionist tactics to prevent ... qualified individuals from receiving up-or-down votes," 18 Bush recess appointed Charles Pickering to the Fifth Circuit in January 2004 and William Pryor to the Eleventh

\footnotetext{
8 Sarah Kellogg, Levin, Stabenow Objections to Judge Ignored, GRAND RAPIDs PrEss, July 3I, 2003, at $\mathrm{A}_{22}$.

9 Sollenberger, supra note 6 , at 146 .

$10 \mathrm{Id}$.

11 Id. at I 44 tbl.2.

12 Goldman, supra note 5, at 905 tbl.2.

13 Id at 904 tbl.I.

14 Sheldon Goldman et al., W. Bush's Judiciary: The First Term Record, 88 JUDICATURE 244, 257 (2005) (quoting "an aide to a senior Democratic senator on the Judiciary Committee").

15 See Denis Steven Rutkus et Al., Cong. Research Serv., RL3 i868, U.S. Circuit and District Court Nominations by President george W. Bush During the IO7 TH-IOgTH CONGRESSES app. 3, at 54-60 (2007).

16 See id. at $54-55$.

17 See id. at $54-60$.

18 Statement on the Recess Appointment of Charles W. Pickering to Serve on the United States Court of Appeals for the Fifth Circuit, 40 WEEkLY COMP. PRES, DOC. 9I (Jan, I6, 2004).
} 
Circuit in February $2004^{19}$ - each of whose nominations had fallen to a filibuster earlier in the same Congress. ${ }^{20}$ (Pickering had also been nominated in the I07th Congress but had not been reported out of committee. ${ }^{21}$ ) Majority Leader Frist echoed the President's language, asserting that the recess appointments were the "proper response to unprecedented obstructionism."22 Minority Leader Tom Daschle, on the other hand, insisted in a floor speech that it was the White House that was flouting established political norms:

In spite of the Senate's judgment, the President has chosen to take the unprecedented step of using recess appointments to bypass the Senate on two occasions. ... At no point has a President ever used a recess appointment to install a rejected nominee on to the Federal bench. ... This White House is insisting on a radical departure from historic and constitutional practices. $^{23}$

He called on the White House to offer "assurances that it will no longer abuse the process and that it will once again respect our Constitution's essential system of checks and balances";24 when that reassurance was not forthcoming, he announced that Democrats would shut down the judicial confirmation process entirely "until we are given the assurance that they will not recess appoint future judges, especially judges who have been rejected by the Senate." 25 The White House rejected the offer, citing the need to use recess appointments in the face of "unprecedented Democratic obstructionism."26

After about a month and a half, a deal was reached: The White House foreswore recess appointments of judges for the remainder of the Congress, and Senate Democrats agreed to allow a floor vote on twentyfive nominees (twenty for district courts and five for courts of appeals). The deal specified, however, that a number of other nominees, including Pryor and Pickering, would not be brought to the floor. ${ }^{27}$

In November of that year, Bush was reelected, and Republicans gained four Senate seats, giving them a total of fifty-five. Within days of the election, Frist announced that, "[o]ne way or another, the filibuster

\footnotetext{
19 Id.; Statement on the Appointment of William H. Pryor, Jr., to Serve on the United States Court of Appeals for the Eleventh Circuit, 40 WEEkLY COMP. PRES. DOC. 259 (Feb. 20, 2004).

20 RUTKUS ET AL., supra note I5, app. 3, at 57-58.

$21 I d$. app, 2 , at 48.

22 Richard B. Schmitt \& Richard Simon, In Rare Move, Bush Installs Judge Pickering, L.A. TIMES, Jan. I7, 2004, at A9.

23 I5O CONG. REC. 5369 (2004).

$24 I d$.

25 Thomas Ferraro, Daschle Vows to Block All Bush Judicial Nominees, REUTERs, Mar. 3o, 2004 .

27 Neil A. Lewis, Deal Ends Impasse Over Judicial Nominees, N.Y. TIMES, May I9, 2004, at AI9.
} 
of judicial nominees must end" in the next Congress. ${ }^{28}$ As the new Congress convened, Frist expanded upon what he meant:

$[I] n$ the last Congress I believe the Senate failed to perform an essential constitutional duty. It failed to offer advice and consent to the President by filibustering ten judicial nominees and threatening to filibuster another six. These filibusters were unprecedented. Never in the history of the Senate has a minority filibustered a judicial nominee who had clear majority support. This was an abrupt and an unfortunate break in more than 200 years of Senate tradition, of Senate history. This tradition must be restored, not merely because we honor the traditions of the Senate, but because this tradition reflects the proper role for this body, the Senate, as designed by our Framers in the constitutional arrangement. ${ }^{29}$

If Democrats would not go along, he threatened, it would become necessary to "change Senate procedures." 30 Frist was threatening to invoke what was variably called either the "nuclear option" or the "constitutional option." In brief, this would involve either (a) the chair ruling that cloture on a nomination was achieved by majority vote with that ruling upheld by majority vote on the floor, or (b) the chair ruling that cloture on a nomination required a supermajority vote with that ruling overturned by majority vote on the floor. The (at least implicit) theory behind either ruling would be that an absolute minority veto would violate a structural constitutional principle of majority rule within a house of Congress. ${ }^{31}$ In making this threat - and in decrying Democratic obstruction as unprecedented - Frist had significant support from conservative media elites. ${ }^{32}$ Democrats, in turn, depicted the threat as a dangerous innovation. In the words of Senator Chuck Schumer, "[f]or

28 Carl Hulse, Frist Warns on Filibusters Over Bush Nominees, N.Y. TIMES, Nov, I2, 2004, at A2I.

29 I5 I CONG. REC. I4 (2005).

30 Id.

31 For a brief discussion of the potential mechanics of the nuclear/constitutional option - advanced in 2004 by a former Frist staffer — see Martin B. Gold \& Dimple Gupta, The Constitutional Option to Change Senate Rules and Procedures: A Majoritarian Means to Overcome the Filibuster, 28 HARV. J.L. \& PUB. POL'Y 205, 260-6I (2004). For one version of the argument that the filibuster is unconstitutional, see Josh Chafetz, The Unconstitutionality of the Filibuster, 43 CONN. L. REV. I003, IOII-I6 (20II).

32 See, e.g., Jay Ambrose, GOP Shouldn't Fear Nuclear Option for Dems' Filibustering Ways, Albuquerque Tribune, Nov. 20, 2004, at $\mathrm{C}_{4}$ ("If Democrats in the Senate continue their unprecedented, unconstitutional, undemocratic, unconscionable tactic of using filibusters to prevent up-or-down floor votes on President Bush's judicial nominees, do not hesitate. Blast their republicharming impudence to smithereens."); Gary J. Andres, Majority Rule on Judges; 'Nuclear Option' is Nothing New, WASH. TLMES, Mar. I7, 2005, at A23 ("Republican leaders are simply demanding the restoration of the status quo in the confirmation process. Labels like 'nuclear option' imply major, unprecedented and pre-emptive actions by Senate Republicans. Not true. It's the Democrats' tactics, filibustering and denying confirmation to majority-supported appellate court nominees, that is 'unprecedented' and 'pre-emptive.'"); Morton Kondracke, Dems Look Like the Extremists Here, CHI. SUN-TIMES, Apr. 22, 2005, at 47 ("If 'nuclear war' befalls the Senate, the blame falls first on Democrats for abandoning normal procedure - full debate — and resorting to the filibuster to block Bush's nominations.”). 
the sake of country and some degree of comity, I would hope and pray that the majority leader would not take away the Senate's time-honored, 200-year-old tradition." 33

Several nominees, including Pickering, asked not to have their nominations resubmitted in the rogth Congress. ${ }^{34}$ But Bush opted to renominate twelve circuit court nominees who had not been confirmed in the previous Congress, including Pryor and several others who had been held up as part of the deal the previous year. ${ }^{35}$ When the renominations were announced, White House press secretary Scott McClellan said in a statement that " $\mathrm{t}]$ he Senate has a constitutional obligation to vote up or down on a president's judicial nominees."36 This appeared to set up a showdown: Democrats' professed views that these specific nominees were sufficiently unfit for judicial office as to warrant a filibuster came squarely into conflict with Republicans' willingness to use majoritarian means of eliminating the filibuster. The conflict was averted at the last minute in late May 2005, when a group of seven Democrats and seven Republicans went around both parties' leadership and reached an agreement to allow several Bush nominees to come to the floor, while preserving the filibuster. ${ }^{37}$ More precisely, the Democrats on the Gang of Fourteen, as it came to be known, agreed for the remainder of the rogth Congress to vote for cloture on judicial nominees except in (undefined) "extraordinary circumstances," and the Republicans agreed to vote against an attempt to lower the cloture threshold for nominees. ${ }^{38}$

Frist was displeased. He announced that he and the rest of the majority leadership had "decided to stand for [the] principle ... [that e]very judicial nominee brought to the floor shall get a fair up-or-down vote." 39 He insisted that:

The proper term for our response is the "constitutional option" because we would rely on the Constitution's power of self-governance to restore Senate traditions barring judicial filibusters. Against their unprecedented power grab by filibuster - that is what I would call the nuclear option there is only one antidote that is certain, that would absolutely be effective, and that is the constitutional option. ${ }^{40}$

33 Hulse, supra note 28.

34 Neil A. Lewis, Bush Tries Again on Court Choices Stalled in Senate, N.Y. TIMEs, Dec. 24, 2004, at AI (noting that Pickering, Carolyn Kuhl, and Claude Allen declined to be renominated).

35 Id.

36 Id.

37 Charles Babington \& Shailagh Murray, A Last-Minute Deal on Judicial Nominees: Senators Agree on Votes for 3; 2 Could Still Face Filibusters, WASH. PosT, May 24, 2005, at A..

$38 \mathrm{Id}$.

39 I5 I CONG. REC. I I, I05 (2005).

40 Id. at I I, Io6. 
The Gang of Fourteen agreement, Frist added, "stops far short of the principle on which this leadership stands." 41 Schumer, on the other hand, celebrated the agreement: "Our robust system of checks and balances has been saved from an unprecedented attack" - that is, the potential abolition of the filibuster. ${ }^{42}$ The agreement quickly resulted in the confirmations of Janice Rogers Brown to the D.C. Circuit, Priscilla Owen to the Fifth Circuit, and William Pryor to the Eleventh Circuit, ${ }^{43}$ but its systemic impact was modest: the rogth Congress saw the rate of confirmation to appellate judgeships tick up to $56 \% .^{44}$ The rogth Congress also saw the confirmations of John Roberts and Samuel Alito to the Supreme Court. While Roberts was confirmed by a vote of seventy-eight to twenty-two, Alito was confirmed by a much narrower vote of fifty-eight to forty-two. ${ }^{45}$ However, cloture was invoked on the Alito nomination by a vote of seventy-two to twenty-five. ${ }^{46}$ All seven Democrats in the Gang of Fourteen voted for cloture, ${ }^{47}$ but only two of them voted to confirm Alito. ${ }^{48}$

In the context of abysmal approval ratings for President Bush, Democrats retook control of both houses of Congress after the 2006 elections, ${ }^{49}$ meaning that a minority filibuster was no longer the President's principal concern when it came to confirming judges. In the I Ioth Congress, only $43 \%$ of Bush's nominees to the circuit courts were confirmed. ${ }^{50}$ The 2008 elections were also good for the Democrats, with

41 Id. Conservative media were also unimpressed. A story in the Washington Times ended with this masterpiece of snark: "Mr. McCain, a chief architect of the deal ... had to leave the press conference before it ended to make an early screening of a movie about himself." Charles Hurt, 7 Republicans Abandon GOP on Filibuster: Reid Hails Party 'Victory'; Bolters Preserve Old Rule, WASH. TIMES, May 24, 2005 , at AI.

42 I5 I CONG. REC. II, II (2005).

43 Sheldon Goldman et al., Picking Judges in a Time of Turmoil: W. Bush's Judiciary During the Togth Congress, 90 JUdiCATURE 252, 265 (2007).

44 Goldman and his coauthors put it at $58 \%$, Sheldon Goldman et al., Obama's First Term Judiciary: Picking Judges in the Minefield of Obstructionism, 97 JUDICATURE 7,8 tbl.I (20I3), but they appear to have missed one unconfirmed nominee. They count twenty-six nominees, whereas there were in fact twenty-seven. See S. REP. No. I09-369, at I22-24 tbl.G (2006) (listing twentyeight nominees, one of whom - Kimberly Ann Moore - was a Federal Circuit nominee and thus omitted from both of our tallies).

45 Goldman et al., supra note 43 , at 27 I.

46 I 52 CONG. REC. $317-I 8$ (2006).

47 Compare the cloture vote at id. with the Gang of Fourteen membership in Hurt, supra note 4 I.

48 Those two were Robert Byrd and Ben Nelson. Compare the confirmation vote at $5_{52}$ CONG. REC. 36I (2006), with the Gang of Fourteen membership in Hurt, supra note 4 I,

49 John M. Broder, Democrats Take Senate, N.Y. TIMEs, Nov. Io, 2006, at AI.

50 Goldman and his coauthors put it at $46 \%$, Goldman et al., supra note 44 , at 8 tbl. , but they appear to have missed one unconfirmed nominee. They count twenty-two nominees, whereas there were in fact twenty-three. See S. REP. NO. III-II, at 32-34 (2009) (listing twenty-four nominees, one of whom - Rod Rosenstein — is mistakenly listed twice). 
Barack Obama winning the presidency and the party significantly increasing its margins in both chambers. ${ }^{51}$ Indeed, for several months of the II Ith Congress, Democrats had a filibuster-proof majority, if the entire caucus held together. ${ }^{52}$ And Obama secured the confirmation of $68 \%$ of his circuit court nominees in that Congress, a significantly higher percentage than was achieved at any point during the Bush Administration. ${ }^{53}$ Moreover, both Sonia Sotomayor and Elena Kagan were confirmed to the Supreme Court with sixty-eight and sixty-three votes, respectively. ${ }^{54}$

But the smooth sailing was not to last: After what Obama referred to as the Democrats" "shellacking" in the 20 Io midterm elections, ${ }^{55}$ their Senate margin was much reduced in the I 2 th Congress, and the confirmation rate for circuit judges dropped back to $57 \% .^{56}$ Moreover, Republicans increasingly drew out each confirmation process by denying unanimous consent, leading to what some academic observers described as "unprecedented obstruction and delay."57 Indeed, in the context of nonjudicial appointments, the Administration got so fed up ${ }^{58}$ that, in January 2012, Obama unilaterally declared the Senate to be in recess, the chamber's convening of pro forma sessions notwithstanding, so as to make recess appointments to the Consumer Financial Protection Bureau (CFPB) and the National Labor Relations Board (NLRB). ${ }^{59}$

51 David M. Herszenhorn, Democrats Widen Their Senate Edge to a Solid Majority, N.Y. Tпmes, Nov. 5, 2008, at PI2; Carl Hulse, Democrats Increase Their Strength in the House, but Lose Some Races, N.Y. TIMES, Nov, 5, 2008, at $\mathrm{P}_{\mathrm{I} 3}$.

52 Democrats' sixtieth seat came when Al Franken was seated in July 2009 , after a lengthy and litigated recount process. See Carl Hulse, What's So Super About a Supermajority?, N.Y. TIMES, July 2, 2009, at AI3. It also would not have come about had Arlen Specter not left the Republican Party and become a Democrat. See Carl Hulse \& Adam Nagourney, Specter Switches Parties; More Heft for Democrats, N.Y. TIMEs, Apr. 29, 2009, at AI. Democrats lost the filibuster-proof edge in February zoio when Republican Scott Brown won the seat previously held by Ted Kennedy. See Carl Hulse \& Jeff Zeleny, G.O.P. Senator Is Sworn In, and Democrats Regroup, N.Y. TIMES, Feb. 5, 2010, at $\mathrm{A}_{\perp 4}$

53 Goldman et al., supra note 44 , at 8 tbl.I.

54 S. REP. NO. I I $2-5$, at $37-38$ (2OII).

55 Peter Baker \& Carl Hulse, The Great Divide: Obama and G.O.P., N.Y. Times, Nov. 4, 2010 , at AI.

56 Goldman et al., supra note 44 , at 8 tbl.I.

57 Id. at 26 .

58 Democrats naturally condemned the obstruction of the executive nominees as unprecedented. See, e.g., I 57 CONG. REC. I9, I85 (20II) (statement of Majority Leader Reid) ("This is the first time in the Senate's history that a party has blocked a qualified candidate solely because they disagreed with the existence of an agency that has been created by law."); id. at I9, I87 (statement of Sen. Johnson) ("Due to an unprecedented and irresponsible display of political gamesmanship, Mr. Cordray's nomination and strong protections for American consumers are being held hostage.").

59 For a brief summary of the facts, see Ryan D. Doerfler, Go Big or Go Home: The Constitutionality of Recess Appointments Following Pro Forma Sessions of the Senate, 65 ADMIN. L. REV. 975, 976-79 (2013). See also CHAFETZ, supra note 6, at 298-99 (noting that congressional obstruction in this context encouraged and justified executive aggrandizement). 
House Speaker John Boehner called the move "an extraordinary and entirely unprecedented power grab... that defies centuries of practice... [and] would have a devastating effect on the checks and balances that are enshrined in our Constitution."60 On the constitutional point, the Supreme Court would at least partially agree, invalidating these appointments in June $2014{ }^{61}$ In the shorter term, some Republicans used the recess appointments as a justification for increased obstructionism on judicial nominees. As Senator Jim DeMint put it, "[u]nless he revokes his unprecedented recess appointments that defied the constitutional role of Congress, I don't intend to support any of his judicial nominees this year." 62

In November 2012, Obama was reelected, and Democrats added to their Senate margin, but they were still well shy of sixty votes. ${ }^{63}$ Confirmation battles came to the fore almost immediately. Although some circuit judges were confirmed in the opening months of the new Congress, ${ }^{64}$ a number of others were held up. Especially upsetting to Democrats was Republicans' refusal to consider three judges nominated to the D.C. Circuit; Republicans asserted that Obama was trying to "pack" the court. ${ }^{65}$ Republicans also filibustered a number of nominees to executive and independent agencies, including several at the cabinet level and those whom Obama had recess appointed in the previous Congress. ${ }^{66}$ By July 20I3, Majority Leader Harry Reid was prepared to eliminate the filibuster for executive and independent agencies by majority vote. ${ }^{67}$ Minority Leader Mitch McConnell declared the threat to be "a very sad day for the Senate. If we do not pull back from the brink, my friend the majority leader is going to be remembered as the worst leader of the Senate ever, the leader of the Senate who fundamentally changed the body."68 Senator Jeff Sessions explicitly linked Republican opposition to the recess appointments: "We shouldn't sit here and

60 Helene Cooper \& Jennifer Steinhauer, Bucking Senate, Obama Appoints Consumer Chief, N.Y. TIMEs, Jan. 5, 20I2, at AI.

61 NLRB v. Noel Canning, I34 S. Ct. 2550 (2014). For a discussion of the use of historical precedent in Noel Canning, see Curtis A. Bradley \& Neil S. Siegel, After Recess: Historical Practice, Textual Ambiguity, and Constitutional Adverse Possession, 2014 SUP. CT. REV. I.

62 Editorial, Obama's Last-Ditch Appointments; Harry Reid Moves to Stack the Judiciary, WAsh. TIMES, Mar. I4, 2012 , at B2.

63 Nicholas Confessore \& Jess Bidgood, Back to Work: Obama Greeted by Looming Fiscal Crisis: Little to Show for Cash Flood by Big Donors, N.Y. TIMEs, Nov. 8, 2012, at AI.

64 See S. REP. NO. II 4-IO, at 4O-44 (2OI5) [hereinafter II3 REPORT] (noting the confirmation of six circuit judges between February and July 2013).

65 David G. Savage \& Kathleen Hennessey, Obama Challenges GOP on Court Appointees, L.A. TIMES, June 5, $20 I_{3}$, at $\mathrm{A}_{7}$.

66 Jeremy W. Peters, Democrats Plan Attack on G.O.P. Filibuster Use, N.Y. TIMEs, July 9, 20I3, at $\mathrm{AI} 5$.

67 Id.

68 I59 Cong. ReC. $S_{5654}$ (daily ed. July I I, 20I3). 
go quietly when the President of the United States — without any legal basis, in my opinion - makes a recess appointment to avoid the confirmation process, and now we object to these people being confirmed after they were in office." ${ }^{69}$ At the last minute, a deal was struck: Republicans would allow votes on seven nominees, including the CFPB nominee who had been recess appointed; Democrats would withdraw the nominations of the two NLRB recess appointees and substitute in their stead two others, who would receive floor votes; and Democrats would not eliminate the filibuster. ${ }^{70}$ The New York Times reported on the deal's warm afterglow: "Though the agreement did nothing to change or save the filibuster in the future, negotiators insisted the deal - and the difficult process that created it - would have far-reaching ramifications in restoring comity and cooperation in the Senate and could create an atmosphere for reaching larger legislative agreements." ${ }^{11}$

That optimism dissipated quickly. ${ }^{72}$ Republicans maintained their filibusters of judicial nominees - their "continued run of unprecedented obstructionism," in Reid's words ${ }^{73}$ — and Democrats soon grew fed up. On November 2I, 20I3, they finally went "nuclear": declaring that Congress "has wasted an unprecedented amount of time on procedural hurdles and partisan obstruction," "74 Reid raised a point of order that "the vote on cloture under rule XXII for all nominations other than for the Supreme Court of the United States is by majority vote." ${ }^{5}$ Senator Leahy in the chair ruled against him, at which point Reid appealed the ruling to the floor, where it was overturned by a vote of fifty-two to forty-eight (including Leahy voting to overrule himself). ${ }^{76}$ It was thus established as an authoritative interpretation of the Senate rules that cloture on all non-Supreme Court nominations was by simple majority. Cloture was then invoked on Patricia Millett's nomination to the D.C. Circuit by a vote of fifty-five to forty-three, ${ }^{77}$ and she was confirmed by a vote of fifty-six to thirty-eight. ${ }^{78}$

\footnotetext{
$69 I d$. at $\mathrm{S}_{5} 658$.

70 Jonathan Weisman \& Jennifer Steinhauer, Senate Strikes Filibuster Deal, Ending Logjam on Nominees, N.Y. Trmes, July I7, 2013, at AI.

71 Id.

72 Indeed, Republicans were complaining within a couple of days. See Jonathan Weisman \& Jeremy W. Peters, Senate Confirms Nominees as G.O.P. Discontent Rises, N.Y. TIMEs, July I9, 20I3, at AI4.

73 Michael A. Memoli, Senate GOP Blocks Obama Picks, L.A. TImes, Nov, I, 20I3, at AI.

74 I59 CONG. REC. S8414 (daily ed. Nov. 2 I, 20I3) (statement of Sen. Reid); see also id. ("Consistent and unprecedented obstruction by the Republican Caucus has turned 'advise and consent' into 'deny and obstruct.'").

75 Id. at $\mathrm{S} 84 \mathrm{I} 7$.

76 Id. at $\mathrm{S} 84 \mathrm{I} 7-\mathrm{I} 8$.

77 Id. at $\mathrm{S} 84 \mathrm{I} 8$.

$78 I d$. at $\mathrm{S}_{5} 84$ (daily ed. Dec. Io, 20I3).
} 
Heralding the move, Obama noted that it came in response to "an unprecedented pattern of obstruction in Congress that's prevented too much of the American people's business from getting done." "Sessions had a somewhat different take, declaring that it constituted "the greatest alteration of the rules without proper procedure that we have probably seen in the history of the Republic." "8o Senator Lamar Alexander echoed the point: "This action by the Democratic majority is the most important and most dangerous restructuring of the rules of the Senate since Thomas Jefferson wrote the rules at the founding of our country." ${ }^{11}$ As a result of the rules change, judicial confirmation rates shot up: in the I I 3 th Congress, 9 I $\%$ of circuit nominees were confirmed. ${ }^{82}$ It was only after the elimination of the filibuster for non-Supreme Court nominees that Democratic appointees began to dominate most of the circuits. ${ }^{83}$

In the 20I 4 elections, Republicans retook the Senate. ${ }^{84}$ In the context of the heightened tensions over judicial nominees, they were not inclined to cooperate with the Administration. Undoubtedly aware of this, Obama barely bothered to put forward any nominees for the circuit courts. Of the eight nominees to the courts of appeals in the II4th Congress, only one was confirmed (Luis Felipe Restrepo, to the Third Circuit). ${ }^{85}$ District court confirmations dropped off as well, although not quite so starkly: of the sixty-three nominees to the trial courts, eighteen were confirmed, for a confirmation rate of $29 \% .{ }^{86}$ The most contentious confirmation battle, of course, came with the Supreme Court vacancy that unexpectedly arose in February 2016.

On February I3, Justice Scalia passed away. That same day, both Majority Leader McConnell and Judiciary Committee Chairman Chuck Grassley announced their view that the next President - that is, the winner of the 2016 election - should nominate Scalia's replacement. Both framed their position in terms of letting "the American people"

79 Remarks on the Procedural Rule Changes in the Senate, 2013 DAILY COMP. PRES. DOC. 795 , at I (Nov. 2I, 20I3).

80 I59 CONG. REC. $\$ 8425$ (daily ed. Nov. 2I, 20I3).

81 Id.

82 See I I 3 REPORT, supra note 64, at 40-44; see also Anne Joseph O'Connell, Shortening Agency and Judicial Vacancies Through Filibuster Reform? An Examination of Confirmation Rates and Delays from Ig8I to 20I4, 64 DUKE L.J. I645, I680-8I (20I5) (noting that filibuster reform "does seem to have uniformly aided judicial nominations: fewer were returned to (or withdrawn by) the President, and successful nominations came more quickly").

83 See Jeremy W. Peters, Eye on Legacy, Obama Shapes Appeals Courts, N.Y. Tmes, Sept. I4, $20 \mathrm{I} 4$, at AI ("Democratic appointees who hear cases full time now hold a majority of seats on nine of the I 3 United States Courts of Appeals. When Mr. Obama took office, only one of those courts had more full-time judges nominated by a Democrat.").

84 Jonathan Weisman \& Ashley Parker, Democratic Seats Fall in Seven States - Repudiation of President Obama, N.Y. TIMES, Nov. 5, 20I4, at AI.

85 S. REP. NO. I I5-I9, at 25-26 (20I7) [hereinafter II 4 REPORT].

86 Id. at $26-33$. 
have a say in selecting the new Justice. ${ }^{87}$ Democrats, naturally, were incensed. In the words of Minority Leader Reid, "[i]t would be unprecedented in recent history for the Supreme Court to go a year with a vacant seat. Failing to fill this vacancy would be a shameful abdication of one of the Senate's most essential Constitutional responsibilities." 88 Vice President — and therefore President of the Senate — Joe Biden insisted that:

[S]aying nothing, seeing nothing, reading nothing, hearing nothing and deciding in advance simply to turn your back before the president even names a nominee is not an option the Constitution leaves open. It's a plain abdication of the Senate's solemn constitutional duty. It's an abdication, quite frankly, that has never occurred before in our history. ${ }^{89}$

Some scholars concurred in the judgment; in their particularly detailed treatment, Robin Kar and Jason Mazzone concluded that:

The historical rule that best accounts for the entire history of Supreme Court appointments is ... the following: . . . the Senate may only deliberately transfer one President's Supreme Court appointment powers to an unknown successor - as Senate Republicans are currently attempting to do with their plan - if there are contemporaneous questions about the status of the nominating President as the most recently elected President. ${ }^{90}$

Obama attempted to neutralize some opposition by nominating Merrick Garland, a D.C. Circuit judge who was respected on both sides of the aisle. ${ }^{91}$ Perhaps more importantly, at age sixty-three, Garland's tenure on the Court would likely have been comparatively short. ${ }^{92}$ Both parties made attempts to use the vacancy and the Garland nomination as cudgels in the 2016 presidential, and especially senatorial, elections, ${ }^{93}$ which had the effect of increasing the issue's salience. ${ }^{94}$ Perhaps because the Court was generally a higher priority for Republican voters

87 Burgess Everett \& Glenn Thrush, McConnell Throws Down the Gauntlet: No Scalia Replacement Under Obama, POLITICO (Feb. I3, 2016, 9:56 PM), http://www.politico.com/story/20I6/02/ mitch-mcconnell-antonin-scalia-supreme-court-nomination-2 I 9248 [https://perma.cc/9 $\mathrm{F}_{2} \mathrm{G}-\mathrm{HS}_{7} \mathrm{G}$ ].

$88 \mathrm{Id}$.

89 Vice President Joe Biden, Remarks at Georgetown Law School About the Supreme Court Nomination, Pol. TRanscriPt WIRE, Mar. 24, 20I6, ProQuest, Doc. No. I 75500680.

90 Robin Bradley Kar \& Jason Mazzone, The Garland Affair: What History and the Constitution Really Say About President Obama's Powers to Appoint a Replacement for Justice Scalia, 9I N.Y.U. L. REV. ONLINE 53, 60 (20I6).

91 See Eugene Scott, Republicans Have Repeatedly Praised Merrick Garland, CNN (Mar. I6, 20I6, 5:I8 PM), http://Www.cnn.com/2016/03/16/politics/merrick-garland-republicans-praise/ index.html [https://perma.cc/L63Z-KHUQ].

92 See Michael D. Shear et al., Obama Pick Engages Supreme Court Battle: Centrist Appellate Judge Is Named - G.O.P. Leaders Refuse to Budge, N.Y. TLMEs, Mar. I7, 2016, at AI.

93 See Nora Kelly, How the Supreme Court Fight Followed Senators Home, THE ATLANTIC (May 4, 20I6), https:/www.theatlantic.com/politics/archive/2016/05/supreme-court-garlandsenate/48I I 22/ [https://perma.cc/8 $\left.\mathrm{A}_{9} \mathrm{~V}-35 \mathrm{CW}\right]$.

94 See Ariel Edwards-Levy, Voters Say Economy, Supreme Court, Are Top Campaign Issues, HUFFPOST (Aug. I5, 20I6), http://www.huffingtonpost.com/entry/economy-supreme-court- 
than for Democrats, ${ }^{95}$ the Republican caucus held firm, and Garland's nomination was returned to the President at the conclusion of the I I 4 th Congress. ${ }^{96}$ Michael Gerhardt and Richard Painter described the blocking of Garland's nomination as breaking "the patterns of more than Ioo years in which the Senate held confirmation hearings for all but two Supreme Court nominees (who had withdrawn their nominations prior to their hearings) and of the Senate's approving every Supreme Court nominee who had strong professional credentials and a judicial ideology within the mainstream of American constitutional law."97

The 2016 elections shocked most political observers: not only did Republicans retain control of both houses of Congress, but Donald Trump defeated Hillary Clinton to become President.98 This meant, of course, that Trump would enter office with a Supreme Court vacancy to fill, but it remained the case that, at least under the terms of the 2013 filibuster reform, cloture on Supreme Court nominees required sixty votes. Trump nominated Neil Gorsuch, a conservative Tenth Circuit judge who had been on a list of potential nominees Trump had released during the campaign. ${ }^{99}$ But even before Trump announced his pick, some Democrats came out in opposition: Senator Jeff Merkley said that he would filibuster any nominee other than Garland, because "[t]his is a stolen seat. This is the first time a Senate majority has stolen a seat."100 After the nomination was announced, Senator Elizabeth Warren also used the "unprecedented blockade of Judge Merrick Garland's nomination to the Supreme Court" as part of her rationale for opposing

campaign-issues-poll_us_57ae4804e4bo6ge7e5057496 [https:/perma.cc/8JSU-9R9v] (noting the "dramatic uptick" in the number of voters identifying the future of the Supreme Court as a top election issue between February and August 2016).

95 Id.

96 II 4 REPORT, supra note 85 , at 25.

97 Michael J. Gerhardt \& Richard W. Painter, Majority Rule and the Future of Judicial Selection, 2017 WIS. L. REV, 263, 266-67; see also id. at 266 (describing "Senate Republican's [sic] . . refusal to act on Judge Garland's nomination" as "unprecedented"); id. at 267 (claiming that recent "Senate obstruction of judicial nominations" more broadly is "unprecedented").

98 Patrick Healy \& Jeremy W. Peters, Democrats, Students and Foreign Allies Face the Reality of a Trump Presidency: Grief and Glee as an Administration Once Unthinkable Takes Shape, N.Y. TIMES, Nov. Io, 2016 , at AI.

99 Michael A. Memoli, A Conservative Choice: Trump Nominates Federal Judge Neil Gorsuch to Fill the Supreme Court Seat Left Vacant by Scalia Nearly a Year Ago, L.A. TIMES, Feb. I, 20I7, at AI. For the Trump campaign's list of potential nominees, see Richard Wolf, Trump's Supreme Court Choices: Reliably Right, USA TODAY, Dec. I, 20I6, at AI.

100 Burgess Everett, Senate Dems Will Filibuster Trump's Supreme Court Nominee, PoLITICO (Jan. 30, 2017, 3:02 PM), http:/www.politico.com/story/20I //0I/senate-democrats-filibustersupreme-court-pick-234368 [https://perma.cc/CA54-JY5A]. 
Gorsuch, ${ }^{101}$ a position echoed by other Democratic senators, ${ }^{102}$ liberal editorialists, ${ }^{103}$ and some scholars. ${ }^{104}$ On the other side of the aisle, Majority Leader McConnell insisted that "oppos[ing] cloture on a partisan basis to kill a Supreme Court nominee never happened before in history, in the whole history of the country."105 Senator John Cornyn echoed that "a partisan filibuster of a Supreme Court nominee" was "unprecedented in American history." 106 Trump publicly urged Senate Republicans to "go nuclear" if Democrats filibustered. ${ }^{107}$ Democrats did indeed filibuster, ${ }^{108}$ and Republicans (arguing again, in McConnell's words, that "our Democratic colleagues have done something today that is unprecedented in the history of the Senate"109) took the opportunity to lower the cloture threshold for Supreme Court nominees to a bare majority, ${ }^{110}$ completing the move that Democrats had begun in $2013 .{ }^{111}$ Gorsuch was confirmed by a vote of fifty-four to forty-five. ${ }^{112}$

Minority Leader Schumer described the lowering of the cloture threshold as "the end of a long history of consensus on Supreme Court nominations."113 Majority Leader McConnell, for his part, insisted that

101 Elizabeth Warren, Opinion, Gorsuch, His Principles Don't Belong on the Supreme Court, Bos. Globe, Mar, 20, 2017 , at A9.

102 See, e.g., Jim Brunner, Sen. Murray to Vote Against Gorsuch, SEATTLE TIMEs, Mar. 25, 2017 , at BI; Craig Gilbert, Baldwin Will Vote No on Court Nominee, MilwaukeE J. Sentinel, Feb. 3, 2017, at A8.

103 See, e.g., James Downie, Opinion, Yes, Democrats Should Filibuster Gorsuch. His Record Shores Why., WASH. POST, Mar. 24, 20I7, at A2I ("The Republican theft of the Supreme Court proceeded apace this week. By any rational measure, we should be in the middle of Merrick Garland's first year on the court. Republicans' unprecedented refusal to even give Garland a confirmation hearing would be reason enough for Democrats to filibuster President Trump's nominee, Neil Gorsuch.").

104 See, e.g., J. Stephen Clark, President-Shopping for a New Scalia: The Illegitimacy of "McConnell Majorities" in Supreme Court Decision-Making, 80 ALBANy L. REv. 743, 743 (20I7) (arguing that Democrats should not "accept the legitimacy" of any decisions in which Gorsuch is the deciding vote); see also id. at 806 ("Justice Gorsuch . . owes his commission to unprecedented ideological manipulation of the appointments process.").

105 Meet the Press - April 2, 20I7, NBC News (Apr. 2, 20I 7, I 2:09 PM) http:/www.nbcnews. $\mathrm{com} /$ meet-the-press/meet-press-april-2-20I7-n74I77 I [https://perma.cc/PFX 4 -59VK].

106 Face the Nation Transcript April 2, 20I7: Haley, Cornyn, King, CBS NEWs (Apr. 2, 20I7, 2:09 PM), https://www.cbsnews.com/news/face-the-nation-transcript-april-2-20I7-haley-cornynking/ [https:/perma,cc/YS5V-2AXZ].

107 Sean Sullivan et al., As Gorsuch Makes Rounds, Trump Talks "Nuclear" Tactics, WASH. POST, Feb. 2, 2017 , at $\mathrm{A}_{4}$.

108 See 163 CONG. REC. $S_{23} 89$ (daily ed. Apr. 6, 20I7) (defeating cloture on the Gorsuch nomination by a $55-45$ vote).

$109 \mathrm{Id}$.

$110 I d$. at $\mathrm{S}_{2389-90}$ (overturning the ruling of the chair by a vote of $52-48$ and subsequently invoking cloture on the Gorsuch nomination by a vote of $55-45$ ).

111 See Josh Chafetz, The Supreme Court Filibuster Died Long Before the GOP Killed It, WASH. PosT, Apr. 9, 20I7, at $\mathrm{BI}$ (arguing that the $20 \mathrm{I}_{3}$ exemption of Supreme Court nominees from majority cloture was highly unstable and therefore that the 2017 ruling was close to inevitable).

112 I63 Cong. REC. S2442-43 (daily ed. Apr. 7, 20I 7 ).

113 Id. at $\mathrm{S}_{2} 388$ (daily ed. Apr. 6, 20I 7). 
the rules reform had reached its conclusion: "I don't think the legislative filibuster is in danger .... There is not a single senator from the majority who thinks we ought to change the legislative filibuster."114 Within weeks, the President was tweeting in favor of eliminating the legislative filibuster: "The U.S. Senate should switch to 5 I votes, immediately, and get Healthcare and TAX CUTS approved, fast and easy. Dems would do it, no doubt! [sic all]"115

$$
* \quad * \quad *
$$

The one constant in each of these conflicts is that each side claims that the other has behaved in an unprecedented manner or forced the nation into an unprecedented situation. That claim then serves to justify some response, which in turn gets characterized as unprecedented. ${ }^{116}$ Indeed, the term "unprecedented," along with a few nearly synonymous phrases ("never before in the nation's history" "defies centuries of practice," "violates a two-hundred-year-old tradition," etc.), arises with such frequency that it takes on an almost ritualistic character. The actual content of the claim fades into the background: Are the events of the last decade and a half really so extraordinary as to be incapable of assimilation into the arc of American constitutional development? What would count as precedent for these events, anyway? And if claims of unprecedentedness are made with such lulling regularity any time there is legislative procedural maneuvering, does the past have any utility for us at all?

\section{THE PASTS}

Any attempt to understand claims of unprecedented behavior necessarily sends us to the historical record, ${ }^{117}$ to try to construct a narrative of the past within which the behavior either fits or does not. Doing so will allow us to think more broadly, not only about the availability (or lack thereof) of "precedents" for activities in the present, but also about

\footnotetext{
114 James Hohmann, Legislative Filibuster May Be Next to Go, WASH. POST, Apr. 7, 2017, at AI 8 .

115 Donald J. Trump (@realDonaldTrump), TwITTER (May 30, 2017, 6:59 AM), https:// twitter.com/realdonaldtrump/status/869553853750013953 [https://perma.cc/UG8L-QGAE]; see also Aaron Blake, Trump Asks for Move Porer. Here's Why the Senate GOP Will Resist., WASH. POST: THE FIX, (May 30, 2017 ), https:/www.washingtonpost.com/news/the-fix/wp/201 $7 / 05 / 02 / 3$-reasonsthe-gop-wont-nuke-the-filibuster-and-give-trump-more-power/ [https:/perma.cc/LW92-SSXA].

116 This is an intracameral analogue to David Pozen's observation that, "under prevailing norms of constitutional argumentation in the separation-of-powers area, allegations that another branch has engaged in unprecedented ... behavior can almost always be mobilized to support a claim of enhanced discretion" by the branch making the claim. David E. Pozen, Self-Help and the Separation of Powers, I24 YALE L.J. 2, 46 (2014).

117 Indeed, in my view, any attempt to understand politics full stop ought to send us to the historical record. See CHAFETz, supra note 6, at 3-6; KAREN ORREn \& STEPHEN SKowroneK, THE SEARCH FOR AMERICAN POLITICAL DEVELOPMENT I-32 (2004).
} 
the choices that go into constructing a precedential relationship and the rhetorical work that claims of unprecedentedness do.

To those ends, this Part offers two historical narratives: one of obstruction in Congress generally, and one of the appointments and confirmation process (with a focus, although not an exclusive one, on judicial appointments battles). The hope is that they will provide usable histories, allowing us to situate recent events within longer narrative arcs of American constitutional development. These narratives will also, as it turns out, demonstrate the deep precedentedness of claims of unprecedentedness in discussions of American legislative procedure.

\section{A. Legislative Obstruction}

One way we might attempt to situate the recent constitutional politics of judicial appointments is with respect to the history of legislative obstructionism more generally. Concern about obstruction began early: the standing rules adopted by both the House and the Senate in the First Congress limited members' ability to speak multiple times on the same topic and provided for the chair to call members to order. ${ }^{118}$ In the Manual of Parliamentary Practice that Thomas Jefferson compiled for his own use as President of the Senate and later published, he wrote that "[n]o one is to speak impertinently or beside the question, superfluously or tediously." 119

Small-scale obstruction of course occurred from Congress's earliest days. In August I 789, when President Washington came in person to the Senate to seek its advice and consent on instructions to be given to treaty negotiators, Senator William Maclay of Pennsylvania called for both the reading of various papers aloud and the commitment of the issue to a select committee, so as to allow the matter to be debated away from the overawing presence of the President. ${ }^{120}$ The delaying tactics worked: after Washington stormed out in frustration, the Senate debated the proposed instructions, altering some and voting others down. ${ }^{121}$ Another incident the following year - this time in the House of Representatives - is sometimes regarded as the first American filibuster: during a debate over where to locate the national capital, Representatives Elbridge Gerry of Massachusetts and William Loughton Smith of South

118 H.R. Journal, Ist Cong., Ist Sess. 9-Io (I 789 ); S. JoURnaL, Ist Cong., Ist Sess. I3-I 4 (1 789 ). Of course, such concerns did not begin with the U.S. Constitution. See CHAFETz, supra note 6 , at 270 (noting early-seventeenth-century rules in the House of Commons aimed at curbing dilatory tactics).

119 Thomas Jefferson, a Manual of Parliamentary Practice $\$$ i 7 , at 36 (Cosimo Classics 2007) (I80I).

120 See CHAFETZ, supra note 6, at $28 \mathrm{I}$.

121 Id. 
Carolina held the floor until their exhausted colleagues agreed to adjourn for the day. Their purpose in doing so was to delay passage of the bill until one of their allies in the Senate, who had been ill, recovered enough to vote against the bill when it got to his chamber. ${ }^{122}$

It is worth reiterating that the "filibuster" over the location of the capital took place in the House, not the Senate. This fact should at least make us begin to question the oft-heard claim that there is something about the Senate's institutional design that makes it inevitably the more obstructive of the two chambers. Indeed, in a groundbreaking study of legislative obstruction in American history, Gregory Koger found that "there was more obstruction in the House than the Senate from 1789 to I90 I." 123 To observers at the time, this fact seemed to follow naturally from institutional design. As Senator Richard Coke of Texas put it in I884:

It is well known ... that bills are passed much more rapidly and with much more facility through the Senate than through the House on account of the difference in the constitution of the two bodies, the one small and compact and the other large and unwieldy. It is also well known that with the expiration of every Congress large numbers of bills which have passed the Senate die on the Calendar of the House from non-action. ${ }^{124}$

But even as Coke was speaking, this was beginning to change. The previous year, the House Rules Committee for the first time reported out a resolution, subsequently adopted by the full chamber, that suspended the normal calendaring rules and allowed a particular piece of legislative business to jump the queue. This was a hugely important innovation: it allowed the Rules Committee to set the agenda for the chamber, and, since the Speaker maintained tight control over (and indeed chaired) the Rules Committee, it in effect allowed the leadership of the majority party to set the agenda. ${ }^{125}$

A few years later, with Speaker Thomas Reed presiding over a slim Republican majority, Democrats began employing a "disappearing quorum" in an effort to bring the business of the House to a standstill: under the extant practices, only members who actually cast a vote were counted for quorum purposes. If all of the Democrats simply refused to vote, and if more than a handful of Republicans were absent, then the chamber would lack a quorum and could do nothing other than adjourn. ${ }^{126}$ By January I890, Reed had had enough: after Democrats

122 See Chafetz, supra note 3 I, at IO23-24.

123 Gregory Koger, Filibustering: A Political History of Obstruction in the HOUSE AND SENATE 39 (20I0); see also id. at 50 fig.3.7 (graphing obstruction in the two chambers between 1789 and $I 901)$.

124 I5 CONG. REC. 309 (I 884).

125 See CHAFETz, supra note 6 , at $285-87$.

126 See id. at 287 . 
refused to vote and thereby deprived the House of a quorum to decide a contested election, ${ }^{127}$ Reed ordered the clerk to record the names of those Democrats "present and refusing to vote" and to count them for quorum purposes. ${ }^{128}$ The next day, Democrats objected to the usually anodyne matter of approving the previous day's Journal and then sought to use a disappearing quorum to prevent the Republican majority from voting to approve it. ${ }^{129}$ Reed again counted the nonvoting Democrats as present for quorum purposes in overruling their objections and approving the Journal. ${ }^{130}$ The debate over the previous day's Journal took the entire day, ${ }^{131}$ and tempers ran high: Democratic Representative Richard Bland of Missouri called Reed "the worst tyrant that ever presided over a deliberative body," to applause from Bland's side of the aisle. ${ }^{132}$

The following day began with a replay of the previous day's drama over the Journal. ${ }^{133}$ Democrat William Bynum of Indiana, who had attempted to move an adjournment before the vote on approving the Journal but had been ignored, was outraged:

Mr. Speaker, it is the first time in the history of this House that the presiding officer has turned his back on a Representative and instructed a mere subordinate of the House to suppress him by calling the roll ... . ...

You have gone forward, sir, you have usurped power, you have mutilated the records of this House to accomplish the scheme that you have deliberately gone to work to carry out.... No tyrant ever ascended the throne but who attempted to vamp up some feeble show of title to amuse the people while he gained possession of the kingdom. You have attempted to vamp up some feeble show to sustain your outrageous rulings . . . 134

But Reed fired back:

There is no possible way by which the orderly methods of parliamentary procedure can be used to stop legislation. The object of a parliamentary body is action, and not stoppage of action. Hence, if any member or set of members undertakes to oppose the orderly progress of business, even by the use of the ordinarily recognized parliamentary motions, it is the right of the

\footnotetext{
127 It was not a coincidence that matters came to a head over an election contest. As Richard Valelly has shown, the contest over the Reed reforms was tied to Republican attempts to maintain electoral power in the South by protecting the votes of African Americans. See generally Richard M. Valelly, The Reed Rules and Republican Party Building: A New Look, 23 STUD. AM. PoL. DEV. I I5 (2009).

1282 I CONG. REC. 949 (I89o).

$129 \mathrm{Id}$. at $977-80$.

130 See id. at 978-80, 993-94.

131 See id. at 994-95 (adjourning).

132 Id. at 977 .

133 See id. at 996-98.

134 Id. at 999.
} 
majority to refuse to have those motions entertained, and to cause the public business to proceed.

...Whenever it becomes apparent that the ordinary and proper parliamentary motions are being used solely for purposes of delay and obstruction; when members break in an unprecedented way ... over the rule in regard to the reading of the Journal ... [i]t is then the duty of the occupant of the Speaker's chair to take, under parliamentary law, the proper course with regard to such matters... ${ }^{135}$

Two weeks later (with Democrats still refusing to vote and still objecting when they were counted for quorum purposes ${ }^{136}$ ), the House adopted a set of reforms to the chamber's standing rules. ${ }^{137}$ The revisions, which would come to be known as the "Reed Rules," were far-reaching and almost uniformly anti-obstructionist in content. Most significantly, they codified the Speaker's power to count the quorum; they provided that "[n]o dilatory motion shall be entertained by the Speaker," while leaving the definition of "dilatory motion" to the Speaker's discretion; and they lowered the quorum threshold in the Committee of the Whole to one hundred members. ${ }^{138}$ Eric Schickler has described the adoption of the Reed Rules as "without question one of the most significant events in the institutional development of the Congress. No single change did more to secure majority rule in the House."139

Democrats took control of the House in the I 890 elections and repealed the Reed Rules in I892. But after Minority Leader Reed led an obstructionist campaign with the sole aim of restoring his anti-obstructionist rules, Democrats reinstated them in 1894 , and Republicans retook control of the House in I895, giving the speakership to Reed once more. ${ }^{140}$ By the end of the nineteenth century, then, the combination of the power vested in the Rules Committee ${ }^{141}$ and the anti-obstruction measures embodied in the Reed Rules had centralized power in the leadership of the majority party to a significant degree, paving the way for relatively frictionless passage of the majority leadership's agenda.

\section{$135 I d$.}

136 See, e.g., id. at $\mathrm{I} 326-27$.

137 Id. at $\mathrm{I} 347$.

138 Id. at I334. On the Reed Rules, see Comm. ON House Admin., History of THE United States House of Representatives, I789-I994, H.R. DOC. NO. I03-324, at I82 \& n.2 I (I994); JAMES GRANT, MR. SPEAKER!: THE LIFE AND TIMES OF THOMAS B. REeD, THE MAN WhO Broke the FILIBUSTER 268-74 (20II); ERIC SCHICKLER, Disjointed PLURALISM: INSTITUTIONAL INNOVATION AND THE DEVELOPMENT OF THE U.S. CONGRESS $32-43$ (200I).

139 SCHICKLER, supra note 138 , at 32 .

140 See CHAFETZ, supra note 6 , at $287-88$.

141 An observer in 1896 noted that "giving very large power to a small committee of five men, the committee on Rules" was part of the "inevitable tendency towards the centralization of power" in the Speaker. M.P. Follett, The Speaker of THe House of RePresentatives 307 (New York, Longmans, Green, and Co. I896). 
Indeed, by the first decade of the twentieth century, Speaker Joseph Cannon, a conservative Republican from Illinois, controlled House proceedings with such ruthless efficiency that a New York Times profile described him as "the greatest absolute monarch on earth":

[I]n Russia the Czar is hedged about by bureaus; in Persia the Shah holds his throne by main strength; the President of the United States has to take counsel with Cabinet, Senate, and House, and the boss of Tammany Hall with his district leaders; but the "Yes" of the Speaker of the House of Representatives passes a bill and makes a law, and the "No" kills it. ${ }^{142}$

But hubris precedes nemesis, and the reaction against Cannon was not far off. In I9I0, a cross-partisan coalition of Democrats and progressive Republicans passed a change to the standing rules taking control of the Rules Committee away from the Speaker. Thenceforth, the Committee would be elected by ballot and would choose its own chair; the Speaker was forbidden to serve on the Committee. ${ }^{143}$ After Republicans lost control of the House the following year, the new Democratic majority changed the rules to provide that the members and chairs of all standing committees would be elected by ballot, further diminishing the speakership. ${ }^{144}$ In practice, a strong seniority system for committee chairmanships became the norm in both parties, ${ }^{145}$ which in turn set the stage for a significant decentralization of power in the House, as long-serving chairs built their own fiefdoms. ${ }^{146}$ In addition, the Legislative Reorganization Act of I 946 aimed at (and was successful at) empowering committees in both chambers by decreasing their numbers, bulking up their staffing, and formally delineating their jurisdictions. ${ }^{147}$ As a practical matter, this meant that tremendous power in the House was in the hands of Southern Democrats for much of the twentieth century, ${ }^{148}$ which of course allowed them to obstruct legislation of which they disapproved. ${ }^{149}$

Again, however, pushback was not far off. Younger, more liberal Democrats began organizing via the Democratic Study Group starting

142 A Glimpse into Speaker Cannon's Famous Red Room, N.Y. TIMES MAG., Dec. I3, Igo8, at 8.

143 ChafeTz, supra note 6, at 288-89.

$144 I d$. at 289 .

145 Id.

146 Nelson W. Polsby et al., The Growth of the Seniority System in the U.S. House of Representatives, 63 AM. POL. SCI. REV. 787 , 802-06 (I969).

147 CHAFETZ, supra note 6, at 292-94.

148 See Eric Schickler, The Development of the Congressional Committee System, in THE OXFORD HANDBOOK OF THE AMERICAN CONGRESS 7 I2, 729 (George C. Edwards III et al. eds., 20II) [hereinafter HANDBOOK].

149 On conservative obstruction generally, see Arthur G. Stevens, Jr., et al., Mobilization of Liberal Strength in the House, 1955-1970: The Democratic Study Group, 68 AM. PoL. SCI. REV. 667, 667,669 (I974). On the strength of Howard Smith of Virginia as Rules Committee chair for much of this period, see Charles O. Jones, Joseph G. Cannon and Howard W. Smith: An Essay on the Limits of Leadership in the House of Representatives, 30 J. POL. 6I 7, 635-38 (Ig68). 
in I959, aiming to provide a counterweight to the procedural conservative biases. ${ }^{150}$ Beginning in the I970s, that push began to bear fruit: a central purpose of the Legislative Reorganization Act of I970 was to curb the power of committee chairs, ${ }^{151}$ and subsequent developments in cameral rules and party organization - including moving away from strict seniority norms - further eroded their influence. ${ }^{152}$ Committee chairs' loss of influence was party leaderships' gain: in the I970s, the Rules Committee again came under the control of the Speaker, and the rise of closed and restricted special rules made that committee more powerful than ever. ${ }^{153}$ The result, by the I980s and I990s, was a "recentralization of power in the speakership,"154 which in turn meant far fewer opportunities for obstruction and delay of the majority party's agenda. (It is entirely possible that events of recent years, including the rise of the Freedom Caucus in the Republican Party and its success in ousting Speaker John Boehner in 20I5, portend another swing of the pendulum in the decentralizing direction. ${ }^{155}$ )

Meanwhile, in the Senate, legislative obstruction remained minimal for most of the nineteenth century. Koger does not identify a Senate filibuster until $183 \mathrm{I} ;{ }^{156}$ for most of the rest of the century, filibusters remained quite rare, and filibustered bills generally passed at the end of the day. ${ }^{157}$ As the Senate grew in size and workload (twelve states were admitted to the Union between the end of the Civil War and the outbreak of World War I), and as the House became comparatively more efficient, attention turned toward obstruction in the upper chamber. On March 4, I9I 7, the Armed Ship Bill, which would have armed the merchant marine against German U-boat attacks, fell to a filibuster when a group of eleven pacifist senators, led by Robert La Follette of Wisconsin, ran out the clock on the Sixty-Fourth Congress. ${ }^{158}$ President Wilson, who had just been sworn in for his second term, was outraged, declaring that a "little group of willful men, representing no opinion but their own, have rendered the great Government of the United States helpless and

\footnotetext{
150 See Stevens et al., supra note I49, at 669-7I.

151 Chafetz, supra note 6, at 294-95; Walter Kravitz, The Legislative Reorganization Act of I970, I 5 LEGIS. STUD. Q. 375, 376-77 (I990).

152 CHAFETZ, supra note 6, at 295 .

153 Id.

154 C. Lawrence Evans, Congressional Committees, in HANDBOOK, supra note 148 , at 396, 400. This development reached its apotheosis with the speakership of Newt Gingrich (I995-I999), whose leadership one observer describes as having transformed the House of Representatives into "the American House of Commons." Sam Tanenhaus, The Power of Congress, NEw YoRkER, Jan. I9, 2015 , at 69,74 .

155 See Ryan Lizza, A House Divided, NEW Yorker, Dec. I4, 2015, at 30.

156 KOGER, supra note I23, at 62 .

157 See id. at 60 fig. 4.3 .

158 Bitter Wrangle as Senate Closes, N.Y. Tпмеs, Mar. 5, I9 I7, at I; see also Chafetz, supra note 3 I, at IO27.
} 
contemptible."159 This, he declared, was "a situation unparalleled in the history of the country, perhaps unparalleled in the history of any modern Government."160 Wilson was not alone in his outrage: at a threethousand-person rally in Carnegie Hall two days later, the names of the filibusterers were greeted with cries of "Traitor!" and "Hang them!"161 Indeed, the public pressure was so intense that some of the "willful men" denied that they had taken part in a filibuster at all;162 by March 8 , after only six hours of debate, the Senate adopted its first cloture rule by a vote of seventy-six to three. ${ }^{163}$ The rule permitted debate on a matter to be brought to a close by two-thirds vote. ${ }^{164}$

Still, for most of the twentieth century, filibusters remained rare in the Senate. Except at the end of a Congress, they required both significant physical endurance and a willingness to infuriate one's colleagues by bringing the business of the chamber to a halt. ${ }^{165}$ As a result, filibusters were largely reserved for issues that raised especially intense opposition - for much of the twentieth century, that meant that filibusters were largely focused on civil rights bills. ${ }^{166}$ But beginning in the I970s, filibusters began to be employed with increasing regularity. ${ }^{167}$ Just as the House was experiencing a backlash against obstructionism during this period, ${ }^{168}$ so too was the Senate. In addition to the Legislative Reorganization Act of I970, described above, the Senate in 1975 lowered the cloture threshold (for everything other than rules changes) to threefifths and instituted a "tracking" system, whereby other measures could move forward while one matter was being filibustered. ${ }^{169}$ These measures, which Koger identifies as emblematic of a broader move from attrition to cloture as the means of ending filibusters, ${ }^{170}$ likely had the

\footnotetext{
159 Woodrow Wilson, Statement (Mar. 4, I9I7), in I7 A CoMpILATION of THE Messages AND PAPERS OF THE PRESIDENTS 82 I7, 82 I8 (I92I).

$160 \mathrm{Id}$. at $82 \mathrm{I} 7$.

161 Great Mass Meeting Here, N.Y. Times, Mar. 6, I9 7 , at I.

162 'Willful Men' Deny Aiding Filibuster, N.Y. TIMEs, Mar. 7, I9I 7 , at 3.

163 Senate Adopts Closure 76 to 3; 'Willful Men' Reply to President; May Call Neqe Congress at Once: Alters Rule of roo Years, N.Y. TIMEs, Mar. 9, I9I7, at I.

$164 \mathrm{Id}$

165 For two different measurements of Senate filibustering across the twentieth century, both of which show a dramatic uptick beginning in the early I970s, see KOGER, supra note I23, at I07 figs.6.3 \& 6.4. For a measurement of cloture votes across this period showing a similar pattern, see Chafetz, supra note $3 \mathrm{I}$, at $1009 \mathrm{tbl}$.

166 See KOGER, supra note I23, at II6-24; Chafetz, supra note 3 I, at IO27.

167 Koger identifies the increase in value of Senate floor time as the causal mechanism. KOGER, supra note $\mathrm{I} 23$, at $\mathrm{I} 33-46$. For my purposes here, the causes are less important than the reactions.

168 See supra $\mathrm{pp}$. II5-I6.

169 Sarah A. Binder \& Steven S. SMith, Politics or Principle? Filibustering in The United States Senate I5, I63 (I997); Walter J. Oleszek, Congressional Procedures ANd THe Policy Process 2 I 2 ( 7 th ed. 2007 ).

170 KOGER, supra note $\mathrm{I} 23$, at $\mathrm{I} 37, \mathrm{I} 47-87$.
} 
unintended consequence of increasing and routinizing the use of the filibuster. ${ }^{171}$ By the I990s, it was accurate to describe the filibuster as nothing more than a sixty-vote requirement for the passage of most business through the Senate. ${ }^{172}$ And by the beginning of the twenty-first century, frustrations had begun to boil over, with consequences that were partly traced in Part I.

$$
* * *
$$

How, then, might we characterize this narrative of legislative obstructionism in American history? Broadly speaking, minorities look for procedural tools - things like the mechanism of quorum-counting or the lack of a formal procedural mechanism to bring debate to a close that they can employ to thwart or delay the majority's agenda. When the obstruction becomes pervasive enough that the majority, over some extended period of time, finds it intolerable, the obstructive tactics are restricted or eliminated. At such flashpoints, both the obstructors and those seeking to eliminate obstruction accuse the other side of unprecedented behavior. This is what happened with Speaker Reed's rulings from the chair and the subsequently codified Reed Rules; it is what happened with the creation of the cloture mechanism in I9 7 ; and it is what happened with the reduction in power of the committee chairs in the I970s. At the same time, legislators are apt to fear that too much centralization of cameral authority threatens their individual prerogatives. The revolt against Speaker Cannon, the recent difficulties of Speakers Boehner and Ryan, and the deliberate pace at which filibuster reform has proceeded in the Senate are all evidence of this worry about overcentralization. The result is a broad pattern of push and pull, of reforms aimed at limiting the minority's ability to obstruct while remaining vigilant against making things too easy for majority leadership.

The judicial appointments controversies of the last decade and a half, traced in Part I, fit this longer historical pattern nicely. The minority party increasingly seizes on the tools of obstruction, frustrating the majority. The majority strikes back, through mechanisms like reducing deference to home-state senators and issuing recess appointments. This, in turn, enrages the minority, which ramps up obstruction still further. There are short-lived attempts (such as those in 2004 and 2005) at restoring the status quo ante in the interest of preventing too much power from being consolidated in the hands of majority leadership, but ultimately the dam breaks, with the majority detonating the "nuclear option" in 2013 and 2017.

\footnotetext{
$171 \mathrm{Id}$. at 178 ("Instead of reducing obstruction, these reforms institutionalized the notion that filibustering was an ordinary element of Senate decisionmaking.").

172 Chafetz, supra note 3 I, at roo8-I I.
} 
Of course, one can characterize many of these moves in such a way as to make the "unprecedented" label fit (or, perhaps, so as to make the events fit the label). But, as this section has demonstrated, one can also locate the events squarely within the longer historical arc of congressional debates over obstructive tactics.

\section{B. Appointments Politics}

One can also locate the events described in Part I within the longer historical arc of American confirmation politics. How much deference should we expect the President to receive in the appointments context? The answer, perhaps unsurprisingly, is that it depends. Confirmation politics has been contentious throughout American history: In I 795, John Rutledge, who was serving as Chief Justice of the Supreme Court under a recess appointment, was voted down on the Senate floor. Rutledge had outspokenly and vehemently opposed the Jay Treaty with Britain, and even though Washington nominated him knowing this, the Federalist press strongly opposed him, and Federalist senators followed suit. ${ }^{173}$ Nor was Rutledge the only high-profile nominee voted down in the early Republic: even with overwhelming Republican margins in both houses of Congress, James Madison's desire at the beginning of his presidency to move Albert Gallatin from Treasury to State was thwarted by opposition in the Senate, ${ }^{174}$ and in ${ }^{18}$ I $_{5}$, Madison was allowed to withdraw Henry Dearborn's nomination as Secretary of War after the Senate had voted to reject him. ${ }^{175}$ In I8II, Madison's nomination of Connecticut customs collector Alexander Wolcott to the Supreme Court was rejected by an astonishing twenty-four-to-nine vote. ${ }^{176}$ These rejections were emblematic of the "deep and bitter estrangement between Madison and his Congresses."177

Other early Presidents faced similar appointments difficulties. In the lame-duck period following his crushing defeat by Andrew Jackson in the I828 election, John Quincy Adams nominated William Creighton and Henry Gurley to district judgeships and John Crittenden to the

\footnotetext{
173 Michael J. Gerhardt, The Federal Appointments Process: A CONSTITUTIONAL AND HISTORICAL ANALYSIS 5I-52 \& 355 n.Io (rev, ed, 2003).

174 See Ralph Ketcham, James Madison: A Biography 48I-82 (I $97 \mathrm{I}$ ).

175 GERHARDT, supra note I 73, at lxi \& lxiii n.I tbl.5.

176 S. Exec. JournaL, it th Cong., 3d Sess. i67 (г8I I). On Wolcott, see Keith E. Whittington, Presidents, Senates, and Failed Supreme Court Nominations, 2006 SUP. CT. REV. 40I, 429-30.

177 Walter Kravitz, Evolution of the Senate's Committee System, 4I I ANNALS AM. ACAD. POL. \& SoC. SCI. 27, 29-30 (I974). In Harlow's even more brutal assessment, "Madison could hardly have played a less important part during those eight uncomfortable years if he had remained in Virginia." Ralph Volney Harlow, The History of Legislative Methods in the PERIOD BEFORE I825, at I96 (I9I7).
} 
Supreme Court. ${ }^{178}$ In all three cases, the Jacksonian-dominated chamber passed a resolution declaring that it was "not expedient to act upon the nomination ... during the present session."179 As John Chambers, an anti-Jacksonian who had served in the House in the previous Congress, wrote to Crittenden, the Jacksonians had an "ulterior object in view. Three of the present Judges of [the Supreme] Court are very old \& becoming infirm. A party ascendancy in the Court is therefore hoped for and will be obtained if possible."180 Chambers expressed his hope that:

[T] here are a sufficient number of the Jackson senators to carry the nomination who will be above disgraceful and degrading party feeling which would snatch from the present executive, the power of appointment to offices for the avowed, or to say the least of it, obvious purpose of reserving it for a successful competitor to reward his partisans. ${ }^{181}$

When it became clear that hope would be disappointed, Chambers lamented in a subsequent letter: "What a set of corrupt scoundrels . . . and what an infernal precedent they are about to set."182

Although Jackson did get to fill those seats with his copartisans, ${ }^{183}$ he ran into a number of problems with appointments as well. Evincing some discontent with Jackson's "spoils system," the Senate rejected ten of his nominees in the first year of his presidency, although four of the ten were subsequently confirmed. ${ }^{184}$ Jackson was handily reelected in I 832 , but the anti-Jacksonians picked up control of the Senate; ${ }^{185}$ in the aftermath, the Senate overwhelmingly rejected the nomination of Benjamin Tappan to a district judgeship, ${ }^{186}$ and it twice rejected Roger Brooke Taney — once to be Secretary of the Treasury and a second time

\footnotetext{
178 S. EXEC. JOURNAL, 2oth Cong., 2 d Sess. 62I (I 828 ) (nominating Creighton); id. at 622 (nominating Crittenden); id. at 630-3 ( 1829 ) (nominating Gurley).

179 Id. at 644 (Crittenden); id. at 645 (Creighton); id. (Gurley).

180 David J. Danelski, Ideology as a Ground for the Rejection of the Bork Nomination, 84 Nw. U. L. REV. 900, 907 (I990) (alteration in original) (quoting Letter from John Chambers to John Crittenden (Dec. 29, I828) (available in John J. Crittenden Papers, Library of Congress, Washington, D.C.)).

181 Id.

182 Id. (quoting Letter from John Chambers to John Crittenden (Jan. 28, I829) (available in John J. Crittenden Papers, Library of Congress, Washington, D.C.)).

183 See Whittington, supra note I76, at 4I6. The Supreme Court seat for which Crittenden had been nominated went to John McLean, which allowed Jackson to appoint someone more accommodating of patronage politics to McLean's old job, Postmaster General. See ChAFETz, supra note 6 , at I Io.

184 See GERHARDT, supra note I73, at 9I; Erik McKinley Eriksson, The Federal Civil Service Under President Jackson, I 3 MISS. VALLEY HIST. REV. 5 I7, 524-25 (I927).

185 The hostility of the Senate in the Twenty-Third Congress toward Jackson can also be seen in its censure of him and declaration that he had breached its privileges - the equivalent of a finding of contempt of Congress. See CHAFETz, supra note 6, at I 74 .

186 S. EXEC. JOURNAL, 23 d Cong., ist Sess. 4I2 (I834).
} 
to be an Associate Justice on the Supreme Court - largely out of unhappiness with his performance as Jackson's recess-appointed Treasury Secretary. ${ }^{187}$ But the congressional Jacksonians did better in the I834 midterms (and picked up a number of Senate seats during the TwentyFourth Congress); ${ }^{188}$ as a result, when John Marshall died in I835, the Senate confirmed Taney as his replacement. ${ }^{189}$

One of the senators who gave Jackson a tough time with his appointments was John Tyler of Virginia. ${ }^{190}$ Tyler had been a lukewarm Jackson supporter before becoming increasingly disenchanted over the course of Jackson's presidency. ${ }^{191}$ He came to identify with the nascent opposition to Jacksonianism, throwing his lot in with the emerging Whig Party in the I830s. ${ }^{192}$ Ultimately, after a number of others declined to be considered or were rejected as unsuitable, he was chosen "by default" as the vice presidential nominee for the first unified national Whig ticket in I840. ${ }^{193}$ When William Henry Harrison became the first President to die in office a mere thirty-one days after his inauguration, Tyler became the first Vice President to ascend to the presidency - and was promptly nicknamed "His Accidency."194 But simple anti-Jacksonianism proved insufficient as a governing platform, and Tyler, who remained a Jeffersonian Republican at heart, was never on board with the legislative agenda that Whigs in Congress (led by Henry Clay) were developing. After vetoing several bills central to that agenda, Tyler was expelled from the Whig Party five months after assuming the presidency, and the party subsequently opposed him at every turn. ${ }^{195}$ Appointments were central to that opposition: in his single term, Tyler had seven rejected cabinet nominations. Three of these rejections were of Caleb Cushing to be Treasury Secretary: Tyler kept nominating him, and the Senate kept rejecting him. ${ }^{196}$ Moreover, Tyler made nine total nominations of five individuals (again, nominating several repeatedly) in an attempt to fill two Supreme Court vacancies. Ultimately, only one was

\footnotetext{
187 Chafetz, supra note 6, at i Io.

188 As a result of growing Jacksonian strength in the chamber, the Senate's I 834 censure of Jackson, see supra note 185 , was officially expunged in 1837 , see CHAFETZ, supra note 6 , at I74.

189 CHAFETZ, supra note 6, at i 10.

190 See, e.g., S. ExEC. JourNAL, 23 d Cong., Ist Sess. 42 7-28 (I834) (noting Tyler's vote against confirming Taney as Treasury Secretary).

191 See Gary MaY, John TyLER 33-47 (2008).

192 See id. at $44,49$.

193 Id. at 53 .

194 Chafetz, supra note 6, at III.

195 See Michael J. Gerhardt, The Forgotten Presidents: Their Untold CONSTITUtional LEGACY 37-6I (2013); see also Josh Chafetz, The Contingency of Partisanship, TAKE CARE (Mar. 27, 20I7), https:/takecareblog.com/blog/the-contingency-of-partisanship [https://perma.cc/G 3 GP-XW 36 ].

196 GERHARDT, supra note I 73, at Io6.
} 
confirmed: Samuel Nelson in I $845 .{ }^{197}$ (Nelson, a moderate Democrat, was confirmed after Democrat James K. Polk won the I 844 presidential election. As Gerhardt notes, "the Democrats [in the Senate] were disposed to approve one of their own, and the Whigs regarded him as a less offensive choice than any of the Democrats Polk was likely to pick."198) Tyler also suffered several failed lower-court nominations. ${ }^{199}$ A President with neither a party nor a popular constituency, it turned out, was unlikely to get the personnel of his choosing through the Senate.

With the death of Zachary Taylor in I850, Millard Fillmore became the second Vice President to ascend to the presidency and the last of the four Whig Presidents. During the Thirty-Second Congress, with Democrats controlling both houses, two Supreme Court vacancies arose. Benjamin Curtis was rather swiftly confirmed to fill the first vacancy, ${ }^{200}$ but the Senate refused to confirm anyone to the second seat, despite Fillmore's nominating three different people between August I 852 and February $1853 .{ }^{201}$ By the time of the second and third nominations, Democrat Franklin Pierce had already been elected to succeed Fillmore - like Tyler, Fillmore could not even find a party to nominate him to run for reelection - and the Senate Democratic majority preferred to hold the seat open for Pierce to fill. ${ }^{202}$

Events surrounding the Civil War also gave rise to some high-stakes appointments politicking. After Lincoln had been elected and Southern states had begun to secede, President Buchanan nominated his Secretary of State (and former Attorney General), Jeremiah Black, to fill the Supreme Court vacancy caused by Peter Daniel's death. ${ }^{203}$ Black was a strong supporter of the Slave Power, ${ }^{204}$ and, as the withdrawal of senators from seceding states had given Republicans a slim Senate majority at the end of the Thirty-Sixth Congress, Black was defeated in a partyline vote. ${ }^{205}$ Several historians have suggested that a number of Republican senators were motivated by the desire to hold the seat open for Lincoln. ${ }^{206}$ Not only did Lincoln get to fill the seat (with Republican

\footnotetext{
197 See Supreme Court Nominations: Present-1789, U.S. SENATE, https:/Www.senate.gov/ pagelayout/reference/nominations/Nominations.htm [https://perma.cc/S $\left.\mathrm{FZ}_{4} \mathrm{~N}_{3} \mathrm{U}\right]$.

198 GERHARDT, supra note I73, at 57.

199 See Michael J. Gerhardt \& Michael Ashley Stein, The Politics of Early Justice: Federal Judicial Selection, I789-1861, I00 IOWA L. REv. 55 I, 56I-62 tbl. (20I5).

200 See U.S. SENATE, supra note I97.

201 Id.

202 GERHARDT, supra note I73, at I49-50.

203 Whittington, supra note i 76 , at 424.

204 See Mark A. Graber, Black, Jeremiah Sullivan ( $1810-83$ ), in The Yale BiographiCAL Dictionary OF AmERICAN LAW 5 I, 5I-52 (Roger K. Newman ed., 2009).

205 Whittington, supra note $\mathrm{I} 76$, at 424.

206 See, e.g., Henry J. ABraham, Justices, PrEsidents, and SENATORs: A History of THE U.S. SuPREME COURT APPOINTMENTS FROM WASHINGTON TO BusH II 3I (5th ed. 2008); Donald Grier Stephenson, JR., The Waite Court ig (2003).
} 
Samuel Miller), but Congress also, in I863, expanded the Court to ten Justices, in order to give Lincoln another appointment. ${ }^{207}$

With Lincoln's assassination in 1865, Andrew Johnson, a War Democrat put on the ticket as a show of unity, became the third Vice President to ascend to the presidency. Like Tyler and Fillmore, he could claim no particularly strong base of either public or congressional authority; like Tyler, he was immediately an outsider to the party apparatus that brought him to power. And to boot, he was famously irascible. $^{208}$ As tensions over Reconstruction escalated, Congress responded by attempting to limit Johnson's power over personnel. In I866, it reduced the size of the Supreme Court to seven Justices (with the Court's membership to decline to that number as serving Justices retired or died), so as to prevent Johnson from getting any appointments. ${ }^{209}$ The following year, both the Tenure of Office Act and a rider to the Army Appropriations Act purported to limit Johnson's power to fire holdovers from the Lincoln Administration, and his impeachment in I 868 was precipitated by his violation of those strictures. ${ }^{210}$ After Johnson's narrow acquittal, he nominated Henry Stanbery as Attorney General. Stanbery had previously held the office from I866 to I868, but he resigned to defend Johnson in his Senate trial. Apparently to punish Stanbery for defending Johnson, his nomination was defeated by an overwhelming vote of twenty-nine to eleven. ${ }^{211}$ (Johnson's nomination of Thomas Ewing to be Secretary of War earlier in I 868 had not even been taken up by the Senate, as Johnson's dismissal of the previous Secretary of War, Edwin Stanton, was the precipitating event for Johnson's impeachment. ${ }^{212}$ ) One of the first laws signed by President Grant in I869 expanded the Supreme Court back to nine Justices, giving him an early appointment. ${ }^{213}$ Grant initially squandered the gift by nominating Ebenezer Hoar, who was widely disliked in the Senate and was voted down on the floor. ${ }^{214}$ Joseph Bradley was confirmed to the seat a couple of months later. ${ }^{215}$

\footnotetext{
207 CHAFetz, supra note 6 , at I I 2 .

208 On Johnson's temperament, see Josh Chafetz, Impeachment and Assassination, 95 MINN. L. REV. 347, 40I-03 (2010).

209 CHAFETZ, supra note 6, at I I2.

$210 I d$. at $\mathrm{I} \mathrm{I} 2-\mathrm{I} 3$.

211 S. ExeC. Journal, 4oth Cong., 2d Sess. 249 (I868); Bruce Tap, Stanbery, Henry, AM. NAT'L BIOGRAPHY ONLINE (Feb. 2000), http:/www.anb.org/articles/04/04-00939.html [https://perma.cc/54ZP-2W8S].

212 R. Owen Williams, Ewing, Thomas, Am. NAT'L BiograPhy OnLINe (July 9, 2008), http://www.anb.org/articles/o7/07-00805.html [https://perma.cc/E53 F-D 3 CB].

213 Chafetz, supra note 6, at II 3 .

214 GERHARDT, supra note I 73, at lxxxi tbl.7, I 55 .

215 See U.S. SENATE, supra note 197.
} 
In I88 I, President Hayes — who had promised to serve only one term - nominated Stanley Matthews to the Supreme Court seat vacated by Noah Swayne. Matthews faced heavy opposition from populist and agrarian groups, who believed he was too close to corporate interests. ${ }^{216}$ He had also been Hayes's lawyer before the special Electoral Commission that had resolved the I876 election in Hayes's favor, and he had helped broker the deal with House Democrats that convinced them to accept the Commission's conclusion. ${ }^{217}$ Democrats had control of the Senate, and they simply ran out the clock, keeping Matthews bottled up in committee. ${ }^{218}$ "To the shock of almost everyone," President Garfield renominated Matthews upon taking office. ${ }^{219}$ With the Senate now evenly divided and some of Matthews's staunchest opponents from the previous Congress gone, he was eventually confirmed by a one-vote margin. ${ }^{220}$

Nor were presidential personnel problems limited to the nineteenth century. In I925, President Coolidge, a Republican, twice nominated Charles Beecher Warren to be Attorney General. Despite Republican control of the Senate, a cross-partisan coalition of Democrats and progressive Republicans twice defeated him, on the grounds that he was too close to big business. ${ }^{221}$ This critique had special resonance in the immediate aftermath of the Teapot Dome scandal, which involved oil companies' bribing Interior Secretary Albert Fall to lease them naval petroleum reserves at low prices, without competitive bidding. ${ }^{222}$ A decade later, Franklin Roosevelt's attempt to "pack" the Supreme Court was famously shot down by Congress in I 937.223 Largely in response to the Court's jurisprudential "switch in time" (especially with respect to federal laws in NLRB $v$. Jones \& Laughlin Steel Corp. ${ }^{224}$ ) and Justice Van Devanter's decision to retire, thus ensuring a New Deal-friendly Court majority in the future, public opinion turned against Roosevelt's plan. ${ }^{225}$ It would be a mistake to view the Court-packing plan as a major defeat for Roosevelt, however: although the Court remained at nine Justices, both its jurisprudence and its composition shifted in the

216 John Anthony Maltese, The Selling of Supreme Court Nominees 38-4I (I998).

217 Id. at 38 .

218 Id. at $4 \mathrm{I}$.

219 Id. at 42 .

220 Id. at $42-43$.

221 GERHARDT, supra note I73, at 165.

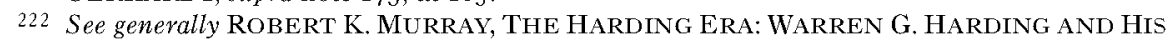
ADMINISTRATION 46I-73 (Ig69).

223 For a lively account of the fight in Congress, see BARRY FRIEDMAN, THE WILL OF THE PEOPLE 223-34 (2009).

224301 U.S. I (I937).

225 See Gregory A. Caldeira, Public Opinion and the U.S. Supreme Court: FDR's Court-Packing Plan, 8I AM. POL. SCI, REV. II39, II47-49 (I987). 
President's preferred direction. By contrast, a couple of decades later, President Eisenhower suffered an unambiguous personnel defeat when he tried to make his friend Lewis Strauss Secretary of Commerce. ${ }^{226}$ In I 958 - mere weeks before the midterm election - Eisenhower recess appointed Strauss to the Commerce post. Strauss had spent years annoying members of Congress of both parties by stonewalling questions in his previous roles as Chair of the Atomic Energy Commission and Special Adviser to the President on atomic energy, and he had especially irritated senior Democrats like Senator Clinton Anderson. ${ }^{227}$ The 1958 midterms were a landslide for the Democrats, and a number of Democratic senators began preparing for a run at the White House in I960. In this context, Eisenhower nominated Strauss to the Commerce position, and Strauss promptly alienated more senators with his dismissive demeanor at his confirmation hearings. ${ }^{228}$ As one historian put it, there developed a "growing sense that no Democratic senator who supported Strauss would have a chance at the party's presidential nomination." 29 Strauss was defeated by a vote of forty-six to forty-nine; an outraged Eisenhower called it "the second most shameful day in Senate history," after only the Andrew Johnson impeachment trial. ${ }^{230}$

And of course a number of late-twentieth-century Presidents had significant trouble with their Supreme Court nominees. This included nominees who were perceived to have ethical liabilities (like Abe Fortas in his nomination as Chief Justice, ${ }^{231}$ Clement Haynsworth, ${ }^{232}$ and Douglas Ginsburg ${ }^{233}$ ), nominees who were simply perceived to be "mediocre" (as Senator Hruska infamously, and unsuccessfully, tried to defend Harrold Carswell ${ }^{234}$ and as a number of Republicans criticized Harriet Miers ${ }^{235}$ ), and nominees who were perceived to be out of the ideological mainstream (as Democrats successfully portrayed Robert Bork $\left.^{236}\right)$. But these stated rationales do not tell the whole story; the surrounding political circumstances are at least as important. Lyndon Johnson nominated Fortas to be Chief Justice in mid-I968. With Johnson not running for reelection and Republicans confident that

\footnotetext{
226 On the Strauss nomination generally, see Richard Allan Baker, A Slap at the "Hidden-Hand Presidency": The Senate and the Lewis Strauss Affair, I 4 CONGRESS \& PRESIDENCY I (I987).

227 ChAFETZ, supra note 6, at $\mathrm{I} 3 \mathrm{I}-32$.

$228 I d$. at 132 .

229 Baker, supra note 226 , at 9.

230 Id. at $\mathrm{I} 3$.

231 See Paul M. Collins, Jr. \& Lori A. Ringhand, Supreme Court Confirmation HEARINGS AND CONSTITUTIONAL CHANGE 22 (20I3).

232 See id. at I 30.

233 See GERHARDT, supra note I73, at I86.

234 See ii6 CONG. REC. 788I (I970).

235 See ABRAHAM, supra note 206, at 320 .

236 See GERHARDT, supra note I73, at I83.
} 
Nixon would win, Fortas was filibustered until Johnson withdrew the nomination, ${ }^{237}$ allowing Nixon to appoint Warren Burger to the chief justiceship. But Democrats still held the Senate (albeit by a reduced margin), and a number of Democratic senators clearly opposed Haynsworth as a form of payback for the defeat of the Fortas nomination, especially given that each was accused of similar improprieties. ${ }^{238}$ Angered by Haynsworth's defeat, Nixon looked for an ideologically similar nominee without the ethical baggage. ${ }^{239}$ But Democrats, emboldened by their defeat of Haynsworth, made issues of both Carswell's ideology and his competence and defeated his nomination as well, resulting in the appointment of the much more ideologically moderate Harry Blackmun. ${ }^{240}$

As a result of the Iran-Contra scandal, Democrats also controlled the Senate when Reagan nominated Robert Bork to the Supreme Court. This control allowed Democrats to stage the hearings in such a way as to win over the public, a task made easier by Reagan's sagging popularity. ${ }^{241}$ Bork's nomination was thus handily defeated, whereas only a year earlier the (then Republican-controlled) Senate had unanimously confirmed his fellow originalist, Antonin Scalia. ${ }^{242}$ The same political circumstances that gave rise to Bork's defeat meant that Douglas Ginsburg was unable to escape the cloud of his past marijuana use and was forced to withdraw. Ultimately, Anthony Kennedy, who was much more palatable to the Democratic majority, was confirmed. ${ }^{243}$

George W. Bush was also deeply unpopular when he nominated Harriet Miers. Despite Republican control of the Senate, she was forced to withdraw when it became clear that many Republicans were not willing to defer to Bush's choice ${ }^{244}$ — but, because of Republican control, the end result was the confirmation of Samuel Alito, who was widely seen to be more conservative. By contrast, after Democrats had retaken the Senate in the 2006 elections and with Bush's public standing at a nadir, Democratic opposition forced him to pick Michael Mukasey as Attorney General rather than several more reliable conservatives whose names had been floated. ${ }^{245}$

237 See id. at $107, \mathrm{I} 26-27, \mathrm{I} 83$.

238 See id. at i88-89; George L. Watson \& John A. Stookey, Shaping America: The Politics of SuPREME Court APPOINTMENTS 40-4I, 48 (I995).

239 WATSON \& STOOKEY, supra note 238 , at $3 \mathrm{I}$.

$240 I d$. at $3 \mathrm{I}-32,48,73-75$.

241 See CHAFETZ, supra note 6, at $22-24$.

242 U.S. SENATE, supra note 197.

243 Chafetz, supra note 6 , at 23.

$244 I d$. at $\mathrm{I} 29$.

$245 I d$. at I $25-26$. 
So how might we characterize this second narrative, this time of struggles over appointments? Put simply, confirmation politics is part of the broader current of interbranch politics, and the determinants of the success or failure of a President's nominees will not be so dissimilar from the determinants of the success or failure of other parts of her agenda. ${ }^{246}$ Or to be a bit more specific, Presidents enjoying success in the public sphere - as measured both by their party's representation in Congress and by more diffuse indicia of public support - are more likely to get the personnel they want confirmed. At the same time, choices of whom to nominate and success or failure in getting those nominees confirmed may affect a President's public standing. ${ }^{247}$ Presidents who have lost or never really had public support will have significantly more difficulty: they may see some nominees stalled or defeated, and they may find themselves forced to nominate suboptimal (from their own point of view) candidates in order to ensure Senate confirmation. This pattern holds across different types of nominees (executive and judicial, higher- and lower-ranking), and it manifests in different procedural forms. Thus, we've seen judicial nominees voted down on the Senate floor, from Rutledge to Bork. We've seen judicial nominees denied votes, from Creighton, Gurley, and Crittenden to Fortas. We've seen cabinet officials blocked, from Gallatin and Dearborn to Strauss.

Once again, the judicial appointments battles of recent years, discussed in Part I, fit into this broad pattern. When Presidents are riding relatively high in the public sphere - as George W. Bush was in the immediate aftermath of his reelection and Obama was in the immediate aftermath of both of his elections - they have relatively more success in the confirmation process, even if doing so necessitates the sorts of procedural changes traced out in the previous section. When they are doing less well overall, they also do less well in confirmations. Thus, Bush did significantly better in the rogth Congress than in the I roth, and Obama enjoyed high success rates in both the I I th Congress, immediately after his election, and the i I 3 th Congress, after his reelection, when Democrats invoked the nuclear option. By contrast, Obama did worse in the I 2 th Congress, after the "shellacking" 248 of the 20 Io midterms, and he did much worse - including, of course, the refusal to consider Garland - in the I I 4 th Congress. ${ }^{249}$

\footnotetext{
246 See generally id. at I I9-34.

247 See id. at 20-24 (discussing the dynamics of political actors' engagement in the public sphere).

248 Baker \& Hulse, supra note 55.

249 As of this writing, it is too soon to say much about Trump's record with judicial appointments. With Republicans in control of the Senate in the II 5 th Congress, and with the elimination of the
} 
As we have seen, some scholars have deemed Senate Republicans' obstruction of the Garland nomination unprecedented. ${ }^{250}$ Recall that Kar and Mazzone induced a "historical rule that... the Senate may only deliberately transfer one President's [I] Supreme Court appointment powers [2] to an unknown successor... if [3] there are contemporaneous questions about the status of the nominating President as the most recently elected President." ${ }^{251}$ Condition (I) is meant to exclude all lower court appointments and nonjudicial appointments..$^{252}$ Condition (2) is meant to exclude the nominations of Crittenden, Black, and Matthews, on the grounds that the identity of the President-elect was known at the time those nominations were made. ${ }^{253}$ Condition (3) is meant to exclude Tyler's nominees, Fillmore's nominees, and the shrinking of the Court's size to prevent Andrew Johnson from getting any nominees confirmed. ${ }^{254}$ Fortas apparently does not count because, al-though he was filibustered and although it was clear that the filibuster would have the effect of handing the nomination to Lyndon Johnson's successor (and indeed it was clear that a number of Republican senators anticipated and desired this outcome), the Senate at least held "confirmation hearings and floor debates."255 (Technically, this is not quite correct: the Senate failed to invoke cloture on the motion to proceed to consideration of the Fortas nomination, and therefore it

\footnotetext{
filibuster for all nominees, it would not be surprising to see high confirmation rates. But Trump's low public standing, see, e.g., Harry Enten, Six Months In, Trump Is Historically Unpopular, FIVETHIRTYEIGHT (July I 7, 20I7, 5:59 AM), https:/fivethirtyeight.com/features/six-months-intrump-is-historically-unpopular/ [https://perma.cc/ $7 \mathrm{RBS}_{-3} \mathrm{TC}_{2}$ ], would suggest that he is unlikely to be afforded great deference, even by copartisans. In this regard, it is telling that one of his original cabinet nominees, Andrew Puzder for Labor Secretary, was forced to withdraw for lack of support in Congress. See Alan Rappeport, Labor Choice Drops Out After Republicans Balk, N.Y, TIMES, Feb. I6, 20I7, at AI. It is certainly possible that the only reason the Senate has not rejected more Trump executive branch and independent agency nominees is that the Administration has been so slow to make nominations. See Karen Yourish \& Gregor Aisch, The Top Jobs in Trump's Administration Are Mostly Vacant: Who's to Blame?, N.Y. TIMEs (July 20, 20I 7 ), https://www. nytimes.com/interactive/20I $/ 07 /$ I $_{7} / \mathrm{us} /$ politics/trump-appointments.html [https:/perma.cc/4AWVM969].

Given his low public standing, we might expect to see Trump nominate judges that Senate Republican leadership would prefer, rather than those that he would most prefer, insofar as he has a discernible view on the matter. Bush's failed nomination of Harriet Miers, followed by his successful nomination of Samuel Alito, may be instructive here: a relatively weak President who nevertheless commands a Senate majority may need to move toward his party in the Senate, because he will be unable to make the congressional party move toward him. In this regard, Neil Gorsuch may look a lot like Alito.

250 See supra pp. 107-09.

251 Kar \& Mazzone, supra note go, at 60.

252 See id. at $76-80$.

253 See id. at $68-72$.

254 See id. at $63-68$.

255 Id. at $8 \mathrm{I}$.
} 
was never considered on the Senate floor. ${ }^{256}$ Given the weight Kar and Mazzone place on formal distinctions, this seems significant.) Fortas also does not count because there was no "actual vacancy," as Earl Warren's retirement took effect upon the confirmation of a successor. ${ }^{257}$ So: if we focus only on nominations to the Supreme Court, and we exclude nominations made after the election of a successor, and we exclude nominations made by Vice Presidents who ascend to the presidency (nine of the forty-five Presidents, although four subsequently won reelection), and we exclude nominations to seats that will not technically become vacant until the successor is confirmed, and we exclude nominations that got a committee hearing, then the Senate's holding open of a seat for the next President was unprecedented. This claim, of course, is not wrong: the description, at that level of specificity, fits the data. But so do many other descriptions: the Senate had never held open a Supreme Court seat for the next President when the nominee's last name began with $\mathrm{G}$, or when the nominating President's last name began with any letter other than A, B, F, H, J, or T. One needs a reason to think that the criteria picked out are explanatory, not merely correlative. For instance, why should it matter per se that Tyler, Fillmore, and Andrew Johnson were Vice Presidents who ascended to the presidency? So were Theodore Roosevelt and Gerald Ford, and both of them had Justices confirmed during the presidential term in which they ascended (Oliver Wendell Holmes and William Day for Roosevelt and John Paul Stevens for Ford). ${ }^{258}$ And if the issue is who gets to shape the bench for the future, why should it matter that Earl Warren's resignation was conditional or that Fortas got a hearing?

An explanation that fits the data equally well — and that, to my mind, at least, is more persuasive as an explanatory matter — is that Supreme Court nominations, like other nominations, are subject to many of the same forces as other parts of the President's agenda. Tyler, Fillmore, and Andrew Johnson had particularly poor standing in the public sphere at the time the Senate refused to allow them to appoint Justices. Failure to get their nominees confirmed was one manifestation of their poor public standing, but there were a number of others. Perhaps most starkly, none of the three was able to convince a major party to nominate him to run for election to the presidency in his own right, ${ }^{259}$ and Johnson was impeached and very nearly convicted. ${ }^{260}$ This poor public standing is not unrelated to how they came into the presidency, as I have traced above. But poor public standing is also not the same

256 II 4 CONG. REC. 28,933 ( ( 968 ).

257 Kar \& Mazzone, supra note 9o, at $8 \mathrm{I}$; see id. at $8 \mathrm{I}-82$.

258 U.S. SENATE, supra note I97.

259 See Gerhardt, supra note I95, at 38 (Tyler); id. at 93 (Fillmore); Hans L. Trefousse, ANDREW JOHNSON: A BIOGRAPHY 336-40 (I989) (Johnson).

260 See Trefousse, supra note 259 , at $3 \mathrm{II}-34$. 
as how they came into the presidency, as Roosevelt and Ford show. Moreover, poor public standing is what they shared with John Quincy Adams, Buchanan, Hayes, and Lyndon Johnson - and it is also what they have in common with Madison throughout his presidency, Eisenhower in 1959, Reagan in 1987 , and George W. Bush beginning in 2005. Politically weak Presidents often don't get what they want, whether that's Social Security reform or Harriet Miers on the bench. Politically strong Presidents do. ${ }^{261}$

\section{CONClusion}

The question about how to construct a usable past matters all the more because of the normative valence it takes on when described as "precedent." Kar and Mazzone do not purport simply to describe past patterns; they add a normative dimension by elevating the pattern they've discovered to the status of a "historical rule" that they apply to judge the permissibility of present practice. ${ }^{262}$ Likewise, the repeated, ritualistic accusations of "unprecedented" behavior by the other side in appointments controversies serve as accusations of misconduct. In these debates, no one ever uses "unprecedented" in a good way. ${ }^{263}$

This means that a lot of normative work is being done by historical accounts. And, in particular, a lot of subsumed normative work is being done by the choices of how to frame those accounts. In Part I of this Essay, I offered my own description of recent judicial appointments controversies. In Part II, I offered two much longer narrative arcs within which the more recent events could be situated: one focused on legislative obstruction and the other on confirmation battles. Just as one could choose to describe the present in different terms than I have, one could also situate it within differently constructed and delineated pasts.

The choice among these is a political choice, and therefore the choice to describe something as unprecedented states a conclusion as much as it does a premise. This of course does not mean that we should stop talking about our present politics in terms of the past. But it does mean that we should be alive as to how political claims about the past are constructed. In the judicial context, Jerome Frank wryly noted that, "[s]omehow or other, there are plenty of precedents to go around" in order to legitimate any particular outcome. ${ }^{264}$ The same dynamic of indeterminacy means that, when seeking to delegitimate any particular outcome, there are plenty of ways of describing it as "unprecedented" to

\footnotetext{
261 For a discussion of the ways in which public standing affects the relative power of political institutions, see CHAFETZ, supra note 6 , at $15-26$.

262 See Kar \& Mazzone, supra note 9o, at 60.

263 Cf. David E. Pozen, Constitutional Bad Faith, I29 HARV. L. REV. 885, 93 I (2016) ("Claims about the other side's 'unprecedented' tactics have ethical content in light of the theory of constitutional conventions; they imply an abuse of process or power." (footnote omitted)).

264 FRANK, supra note 2 , at 152.
} 
go around. This is because every claim of unprecedentedness rests on a particular way of telling the story of what came before. For the claim to be persuasive (and therefore potentially capable of bearing normative weight), we must first find the story about the past to be persuasive. And because of the normative valence of these historical claims, persuasiveness must entail more than just factual accuracy; it must also entail the belief that this is the right framing, that the right facts have been picked out as relevant and worthy of being formed into a narrative. After all, it was accurate in 2015 to say that no President whose last name began with $\mathrm{O}$ had ever been denied a Supreme Court appointment so that the Senate could hold it open for his successor. But the claim that there was a precedent applicable to thus-named Presidents is unpersuasive because we do not generally consider stories about our political life that focus on the alphabet to be compelling. Telling a persuasive story requires thinking about the events of the past in context and constructing a narrative with explanatory force. The mere incantation of unprecedentedness cannot short-circuit that much broader historical inquiry.

By examining the broad sweep of American history, this Essay has sought to combat the presentist tendency to take current, familiar arrangements as preordained or natural consequences of hardwired institutional design. Thinking about what political interactions have produced what outcomes across time enables us to evaluate how such interactions in the present are likely to play out. And taking the issues at a high level of generality — asking about legislative obstruction and about the relative balance of power between the President and the Senate in getting nominees confirmed - allows us to think through how specific procedural tools and mechanisms are used to achieve the ends of the political actors, rather than getting caught up on those tools and mechanisms themselves. These narratives of course do not answer stilllive questions on topics such as the future of the legislative filibuster, ${ }^{265}$ the future of senatorial courtesy, ${ }^{266}$ or the posture other political actors may take toward the Court in the future, ${ }^{267}$ but they do give us a broader context in which to situate these questions, as well as some assistance in thinking them through. For those reasons, I find them to be persuasive accounts of the past for the purpose of understanding recent controversies over judicial appointments. Within this broad temporal and substantive frame, it is possible to situate the events of recent years. Other accounts - ones with narrower temporal or substantive

\footnotetext{
265 See supra p. I I0,; see also CHAFETz, supra note 6, at 300-OI; Chafetz, supra note I I I.

266 See supra pp. 97-98; Lydia Wheeler, GOP Talks of Narrowing 'Blue-Slip' Rule for Judges, The HILL (May 20, 20I7, 4:29 PM), http:/thehill.com/homenews/senate/334296-gop-talks-ofnarrowing-blue-slip-rule-for-judges [https://perma.cc/VY6M-QZDB].

267 See Clark, supra note Io4, at 743 .
} 
frames - may make recent events appear to be outliers, even unprecedented. Political actors describing the moves of their antagonists therefore have an incentive to apply a narrower frame - and, as Part I demonstrated, apply it they do. But that narrower framing also runs the risk of impoverishing our understanding of American politics and depriving us of the resources with which to engage the issues of the present moment.

When confronted with a claim in constitutional politics that some actor is engaged in unprecedented behavior, then, the first question we should ask is: Under what framing of the past? And the second question should then be: Do we find that framing of the past to be helpful? Does it illuminate more than it obfuscates? If so, we should be willing to draw conclusions from it. If not, then not. There is, after all, plenty of precedent for unpersuasive claims of unprecedentedness. 